\title{
Kargapazarı Dağları ve Çevresinde (Erzurum Kuzeydoğusu) Yaylacılık Faaliyetleri
}

\section{Transhumance Activities in the Kargapazart Mountains and their Surroundings (North East of Erzurum Province)}

\section{Esen DURMUŞ ${ }^{1}$ (D)}

${ }^{1}$ Fırat Üniversitesi, Eğitim Fakültesi, Türkçe ve Sosyal Bilimler Eğitimi Bölümü, Sosyal Bilgiler Eğitimi Bilim Dalı, Elazığ, Türkiye

ORCID: E.D. 0000-0003-1011-8785

\section{öz}

Doğu Anadolu Bölgesi yaylacılık için son derece uygun coğrafi şartlar taşımaktadır. Türkiye'nin en önemli yaylacılık merkezine karşılık gelen Erzurum-Kars yaylaları Türkiye'de yaylacılık faaliyetlerinin en üst zonunu oluşturur. Erzurum'un kuzey ve güneyinde yoğunlaşan yaylacılık faaliyetleri aynı zamanda hareketinson durak noktasına karşılık gelir. Erzurum'un kuzeyinde Çoruh - Kelkit Sıradağlarına karşılık gelen Kargapazarı Dağlık Ünitesi hem yerli halk hem de göçebe grupların en önemli ekonomik yararlanma sahasını oluşturur. Daha alt zonlarda yer alan göçebe gruplar özellikle de Doğu ve Güneydoğu Anadolu bölgelerinde bulunan sürü sahipleri bu alanın taşıdığı coğrafi şartlara bağlı olarak yoğun bir şekilde bu yaylalardan faydalanmışlardır. Kargapazarı Dağları hidrografik açıdan üç havzaya kaynak oluşturmaktadır. Geniş çayır ve mera alanlarına sahip olmasının yanında kütlenin yüksek platolardan oluşması ve karın 110-120 gün yerde kalması bu alanı Türkiye'nin önemli bir yaylacılık merkezi yapmıştır. Sahada toplu köylerin yanında mezra, kom ve yayla yerleşmeleri de yer almaktadır. Kargapazarı Dağlarına Elâzığ, Diyarbakır, Urfa ve Tunceli'den gelen göçer gruplar daha çok Büyükdere, Başören, Tımar, Şenyurt, Köşk, Büyüktüy, Serçeboğazımahallelerine yaylacılık faaliyetleri için çıkmaktadırlar. Bu köyler Asıl Kargapazarı dağlık kütlesi üzerinde yer almaktadırlar. Yaylacılık faaliyetinin süresi yükseltiye bağlı olarak değişmekle beraber Haziran-Eylül tarihleri arasında yapılmaktadır.

Anahtar kelimeler: Yaylacılık, Kargapazarı, Yerleşme tipi

\section{ABSTRACT}

The Eastern Anatolia Region has highly favorable geographical conditions for transhumance. The Erzurum-Kars highlands, Turkey's most important center of transhumant pastoralism, constitute the upper zones of transhumance activities. The concentration of transhumance activities to the north and south of Erzurum also corresponds to the furthest reaches of pastoralism activities. The Kargapazarı Mountain Unit, located on the Çoruh - Kelkit Mountains to the north of Erzurum, constitutes the most important economic utilization area for indigenous and nomadic groups. The nomadic groups in the lower zones, especially flock owners, have greatly benefited from these highlands. The Kargapazarı Mountains are the source of three hydrographic basins. In addition to wide meadows and pastures, the area consists of a high plateau and snow stays on the ground for 110-120 days, making this area one of Turkey's most important transhumance centers. Besides the villages, there are hamlets, mountain houses and plateau settlements as well. The nomadic groups coming to the Kargapazarı Mountains from the provinces of Elâzığ, Diyarbakır, Urfa and Tunceli mostly climb up to Büyükdere, Başören, Tımar, Şenyurt, Köşk, Büyüktüy, Serçeboğazı to find summer pasture for their animals. Even though the duration of this transhumance activity depends on the specific altitude of each location, it is generally carried out between the months of June and September.

Keywords: Transhumance, Kargapazarı, Settlementtype

Başvuru/Submitted: 02.12.2019 • Revizyon Talebi/Revision Requested: 05.02.2020 • Son Revizyon/Last Revision Received: 13.02 .2020 • Kabul/Accepted: 15.03 .2020 - Online Yayın/Published Online: 20.04 .2020 


\section{EXTENDED ABSTRACT}

The Highlands of Turkey contain settlements and living units that have a completely different economic character to other parts of the country. The Eastern Anatolia Region has very favorable geographical conditions for transhumance. When we analyse the climate, hydrography, vegetation and values of land use in a relational manner, it is easy to understood why transhumance activities are concentrated in this area.

Livestock farming in Turkey has always faced problems. While the decrease in pasture areas leads to decreases in the number of animals, the prohibition of climbing up to the highlands due to periodic security problems adversely affects livestock. In the Eastern Anatolia Region, which is one of the main livestock production regions of Turkey, the fact that transhumant pastoralism has not reached its potential has been considered to be a problem. In this study on the highlands of Kargapazar1, we obtained our data from the Agriculture Directorates of Erzurum, Pasinler, Narman, Oltu and Yakutiye, and we conducted interviews with village headmen while also undergoing field studies as well as analysing TUIK population and livestock statistics.

The Kargapazarı Mountains are an extension of the Çoruh-Kelkit Mountain Range in the Erzurum-Kars section of the Eastern Anatolia Region to the northeast of the Erzurum Plain. It is a mountainous unit extending in a NE-SW direction between the districts of Yakutiye, Tortum, Narman, Oltu and Pasinler. The streams that originate from this mountainous mass flow into three different basins. Formed of the rivers included in the basins of the Black Sea and the Persian Gulf, this area is like a roof in terms of hydrography.

The rural population of the villages located in the study area decreased by $48 \%$ between 1980 and 2018 . When we look at the distribution of the settlements in Erzurum, the highest unit is seen in the village settlements (1,093 villages). These settlements are followed by 537 hamlet-neighborhoods, 420 highland and 125 mountain house settlements. Across the province of Erzurum, while there was a $50 \%$ decrease in the number of small cattle in a 23 -year period, cattle breeding increased by $32 \%$. The mountain house settlements are important for transhumance activities. In the Kargapazarı mountain range peaks are approximately $2100 \mathrm{~m}$ high and reach as high as $2400 \mathrm{~m}$ in the highlands. The altitude of the highland settlements decreases towards the northeast. The Asıl Kargapazarı mass and the altitude of the highlands around the Devre Mountain start from 2200m going up to as high as 2700m.

Highland peoples carry out their transhumance activities by renting the highlands here for a period of 3 months between 1 and 10 June and 1 and20 September. The most preferred areas are the highlands of Büyükdere, Başören and Köşk villages and the areas where the Tortum and Büyükdere rivers are located on the Asıl Kargapazarı Mountains. These areas correspond to an altitude of approximately $2500-2800 \mathrm{~m}$ which is densely fragmented in hydrographic terms. This area of Turkey is one of the main zones where intense transhumance activities are carried out. Namely, this is an area in Turkey where a severe continental climate type is seen with an average annual temperature of $5-10^{\circ} \mathrm{C}$. While it constitutes the source point of three different basins in terms of hydrography, it is an important area in which $24 \%$ of summer rains are seen after spring and large meadow areas are present. The number of snow covered days in this zone varies between 83 and112 days. Therefore, migration to this zone from the areas of the Upper Euphrates Section and the Southeastern Anatolia Region in Turkey, where snow cover leaves the ground early and the grasses turn yellow early, starts in April and gradually forms the furthest reach of transhumance activities after crossing the highlands.

Nomadic groups coming to the Kargapazarı highlands from the provinces of Elâzı̆ğ, Tunceli, Diyarbakır and Şanlıurfa have prioritized security concerns in other areas of the Eastern Anatolia Region. Compared to other areas (Bingöl-Şerafettin- South of Muş -MunzurMercan Masses), this is a relatively safe zone where no terrorist activities have been observed. In addition, another important criterion for its preference for transhumance activities is that it offers very convenient conditions in terms of transportation.

There are a total of 96 highland settlements in the districts of Otu, Narman, Pasinler, Tortum and Yakutiye including the Kargapazarı Mountainous Unit and 30 highlands in the study area. Even though the altitudes change, the altitude decreases as we move towards the northeast direction. The areas where the highlands are clustered on the mountainous unit are the Kargapazarı Mountainous Mass, Devre Mountain and Çatal Mountain. While the Yakutiye and Pasinler highlands are located on the main mountainous masses, the Tortum and Narman plateaus are mainly located on the Devre Mountain and the Oltu plateaus in the plateau areas of the Çatal Mountain. 


\section{GİRISs}

Göçebe hayvancılık ve yaylacılık faaliyetleri çeşitli fonksiyonları ile coğrafya dışında birçok farklı bilimin de konusunu oluşturmuştur. Coğrafya bilimi, yaylacılık faaliyetlerinin mekânsal ilişkileri, dağılışı ve bu dağılışın nedenlerini baz alarak açıklar (Yiğit, 2015: 133). Ülkemizde göçebe hayvancılık ve yaylacılık konusunda yapılan araştırmalar geçmişten günümüze kadar yaylacıllğın fonksiyonel değişimine göre ele alınmıştır. İlk çalışmalar daha çok yayla kültürü ve göçebe hayvancılık faaliyetlerine yönelik iken 1990'lı yıllardan sonra turizm ve ticari boyutu da ele alınarak değişim ve gelişim vurgulanmaktadır (Tuncel, 2015: 7). Yaylacılık faaliyetlerinin yapıldığı yerlerde kar örtüsünün miktarı ve süresi rasatların yapıldığı alanlara göre oldukça farklıdır çünkü rasat istasyonları, yayla alanlarına göre daha az yükseltiye sahiptir. Genellikle bu sahalarda kar yağışının süresi, miktarı ve kar örtüsünün yerde kalma dönemi daha uzundur. Bu nedenle hayvancılık faaliyetleri gerilemekte ve bunun yerini turizm ve rekreasyon faaliyetleri almaktadır (Yiğit, 2015: 136-142). Doğu Anadolu Bölgesi'nde karın yerde kalma süresinin uzunluğu ve vejetasyon süresinin kısalı̆̆ı hayvancılıkla uğraşan grupların Erzurum çevresine yönelmesine neden olmaktadır.

Orta Asya' da konar-göçer bir hayat yaşayan Türk toplulukları kurdukları yerleşim merkezleri çevresinde bu hayat tarzını devam ettirerek zamanla yerleşik hayata geçmişler ve yaylacıllı̆ı sadece bir ekonomik faaliyet değil aynı zamanda bir geleneksel yaşam biçimi haline getirmişlerdir (Kutlu, 1987: 7).Türkiye'de geniş sahalarda yüzyıllardan beri uygulanan ve halk türkülerinde sık sık dile getirilen yaylacılığın temeli genellikle iklim özelliklerine bağlanarak sıcak mevsimde kurak ve alçak sahalar ile nemli dă̆ otlakları arasında mevcut coğrafi farklardan kaynaklanan hareketliliklerden oluşmaktadır (Merriam, 1926: Akt: Erinç, 1972: 185). Anadolu Türkler tarafindan yurt edinildiği dönemlerde kırsal yerleşme düzeninin oldukça bozuk olması sonucunda Türk boylarının bir kısmı mevcut köy ve şehirlere yerleşirken önemli bir kısmı da konar-göçer hayat tarzını devam ettirmişlerdir (Erinç, 1972: 186-187).

Alagöz'e göre (1941) yayla terimi, köy sürülerinin yazın en sıcak devresinde çıkıp uzun süre kaldıkları dağ merası, Darkot'a (1975) göre, ot sağlamak amaciyla, sürülerin dağ sıralarındaki yamaç ve düzlüklere yayılması anlamını taşımaktadır. Tunçdilek'e (1967) göre yayla, hayvancılık, tarım, turizm ve rekreasyon gibi ekonomik faaliyetlerin sürdürüldüğü bir alana karş1lık gelmektedir (Tunçdilek, 1967: 138). Doğanay ve Zaman (2004) ise oba ve yaylak yerleşmelerini, alçak kesimlerdeki daimî yerleşmelerde oturan ailelerin yaz aylarında yüksek platolara sürüleri ile birlikte çıktıkları geçici olarak yerleşilen basit inşa edilmiş taş yapı kümeleri olarak tanımlamışlardır (Doğanay, Zaman, 2004: 12).

Emiroğlu (1977) yaylacıllğı, toprağa bağlı olmayan, çadır hayatı yaşayan, ekonomik faaliyeti yalnızca küçükbaş hayvan yetiştirmeye dayanan, mevsimlik yer değiştirme hareketinin yanında akrabalık ve soy ilişkileriyle birbirine bağlı olan, kendi içinde bir toplumsal örgütlenme gösteren göçebe aşiretlerin yürüttüğü faaliyetler olarak tanımlarken yerleşik hayata geçiş dönemi ile birlikte "göçebelik" kavramının yerine "yarı göçebelik" kavramı da kullanmıştır. Yarı göçebelik, göçebelikten yerleşik hayata geçerken göçebelik sisteminde meydana gelen değişimi ifade eder. Yaylacılıktan farklı olarak kışlar genellikle konutlarda geçirilir (Emiroğlu, 1977: 2,Sözer, 1972: 37). Hütteroth’a göre, gerçek göçebelik veya göçebe çobanlıkta; hayvan sahipleri ve ailelerinden meydana gelen etnik gruplar sürülerle beraber göç eder, hayvanlardan elde edilen ürünler esas itibariyle göçebeler tarafindan tüketilir (Hütteroth, 1959; aktaran Denker, 1960: 137). Yaşadıkları bölgeye göre "Türkmen", "Yörük", "Göçer" ve günümüzde de yerleşik hayata geçilmesi ile birlikte "Yarı Göçebe" olarak adlandırılan bu topluluklar hayvancıllığa bağlı ekonomileriyle, yerleşik hayat ile göçebelik arasında ara tip yerleşme olarak görülür(Durmuş, Çağlıyan, 2010: 84).

Kutlu (1984) Göçebe kültürünün kır yerleşme düzenini etkilediğini dağınık ve toplu birçok yerleşim biriminin oluşarak yerleşme sayısının arttığını ve yerleşme dışı kalmış alanların da iskanından bahsetmiş̧ir (Kutlu, 1984, 76,77). Alagöz sadece yayla alanlarını değil yüksek alanlarda kurulan kom, kışlak, mezra, ağıl gibi köy altı yerleşme birimleri de yaylacılık faaliyetlerinin yürütüldüğünden (Alagöz, 1993: 40) bahsetmiş̧tir. Yükseltiden dolayı Kargapazarı dağlık ünitesinde de yerleşik ve yarı göçebe hayat tarzını sürdürenler yayla alanları yanında kom, mezra, oba ve kışlak yerleşmelerinde de benzer faaliyetleri yürütmektedirler. Doğanay ve Coşkun (2013) yaylacılık, nomandizm ve göçebe hayvancılık kavramlarının benzer ve farklı yönlerine vurgu yaparak, yaylacılıkta hem yerleşik hem de göçebe iki yerleşme bölgesi arasında düzenli olarak yapılan bir hareketten, buna karşılık göçebe hayvancılıkta ise belirli bir yerleşme ünitesi söz konusu olmayıp sürekli bir otlak arayışı hareketinden bahsetmiştir (Doğanay, Çoşkun, 2013: 5).

\section{2. ÇALIŞMA ALANI}

Kargapazarı dağları, Doğu Anadolu Bölgesi’nin, ErzurumKars Bölümü’nde, Erzurum Ovası kuzeydoğusunda, Çoruh- 
Kelkit Sıradağlarının bir uzantısıdır. İdari açıdan Yakutiye, Tortum, Narman, Oltu ve Pasinler ilçeleri arasında kalan KD-GB doğrultusunda uzanan bir dağlık ünitedir (Şekil 1). Erzurum ilinin kuzeydoğusunda yer alan Kargapazarı Dağları Doğu Anadolu ve Karadeniz Bölgeleri arasında bir geçiş özelliği göstermektedir. Kargapazarı Dağlık Ünitesinin güneyinde Erzurum ovas1, kuzeyinde Rize-Kaçkar Dağları, doğusunda Ağrı, Kars volkanik alanları gibi farklı morfolojik birimlerle çevrilidir.

\subsection{Fiziki Coğrafya Özellikleri}

Kargapazarı Dağlık ünitesi üzerinde, birbiri ile eşiklerle bağlantılı havzalar, geniş plato sahaları,dağ içi ovaları ve derin vadiler görülmektedir. Bu topografik çeşitlilik farklı iklim ve bitki örtüsünün oluşmasına neden olmakta ve yaylacılık için önemli olan çayır ve mera alanlarının oluşmasına yol açmıştır. Tektonik hareketlere bağlı oluşan havzaların ortalama yükseltisi 1700-1800 m olup yükseltisi 2500-3000 m arasında değişen dağlık kütlelerle sınırlandırılmaktadır.

Kargapazarı Dağları'nın yapısı Üst Miyosen-Pliyosen volkanitlerinden oluşmaktadır (MTA, 2002). Volkanik yapı özelliği nedeniyle çevresindeki havzalara göre ortalama $1000 \mathrm{~m}$ daha yüksekte kütlevi bir yapı özelliği göstermektedir (Şekil 2). Arazinin volkanik bir yapıya sahip olması, endemik bitki türleri açısından zengin olmasına neden olmuştur. Dağlık kütle üzerindeki zirveler dışında kalan alanların volkanik plato özelliğinde olması nedeniyle yaz mevsiminde hayvancılık

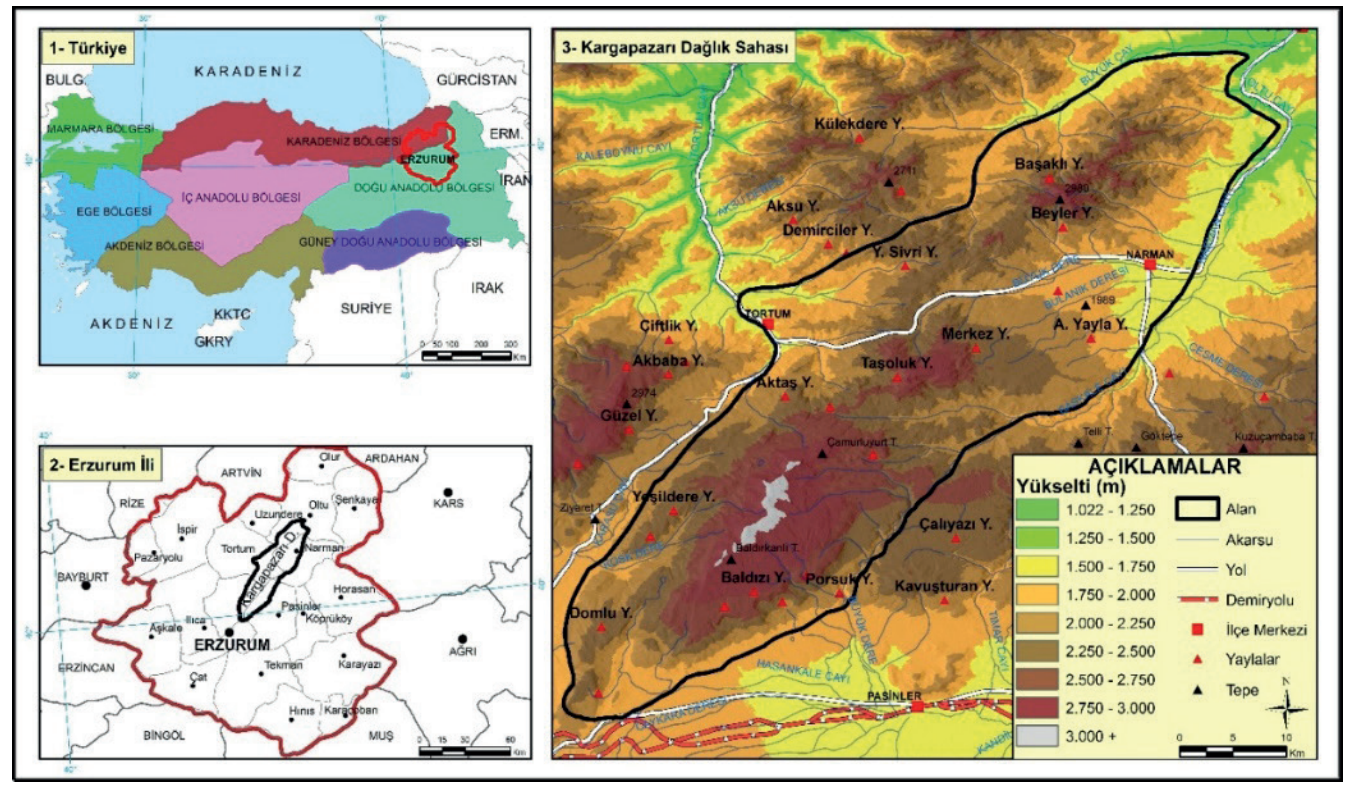

Şekil 1: Kargapazarı Dağları ve çevresinin (Erzurum Kuzeydoğusu) lokasyon haritası.

Figure 1: Location map of Kargapazarı Mountains and its surroundings (Northeast of Erzurum).

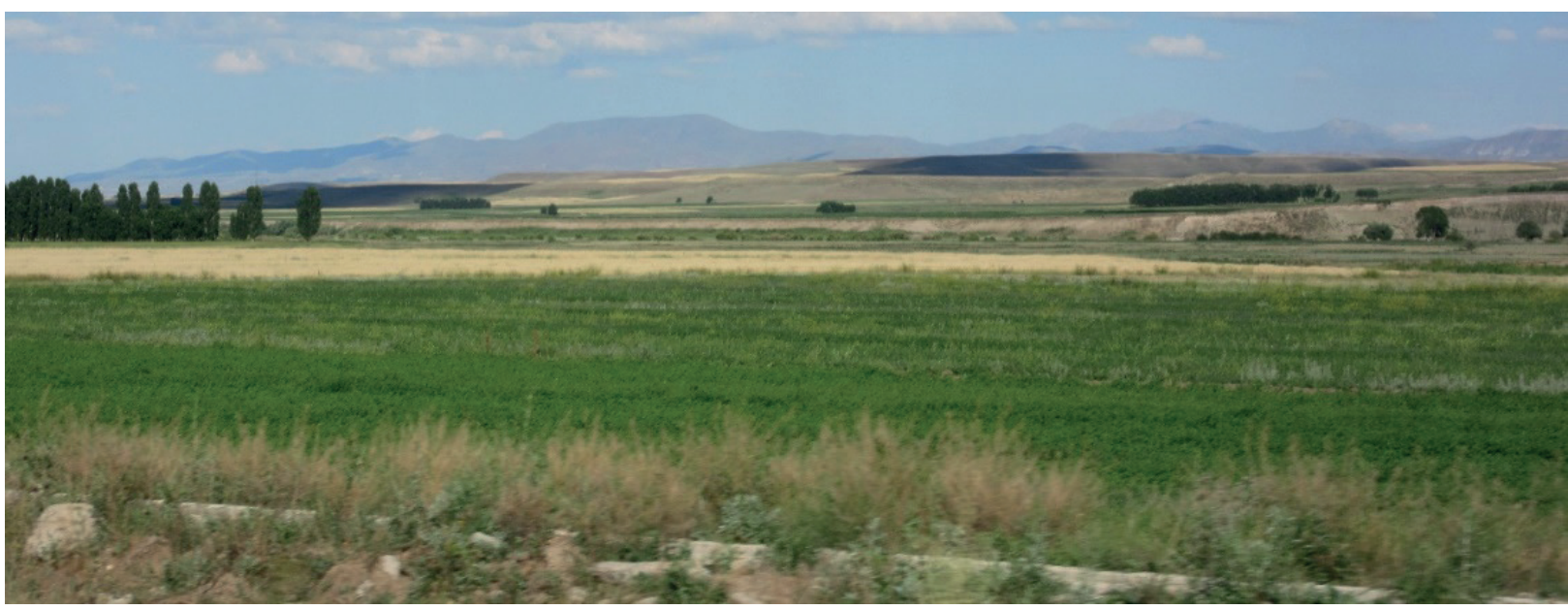

Foto 1: Pasinler ovası kuzeyinde uzanan Kargapazarı dağlık ünitesi (Temmuz-2018)

Photo 1: Kargapazarı mountainous unit extending in the north of Pasinler plain (July-2018) 


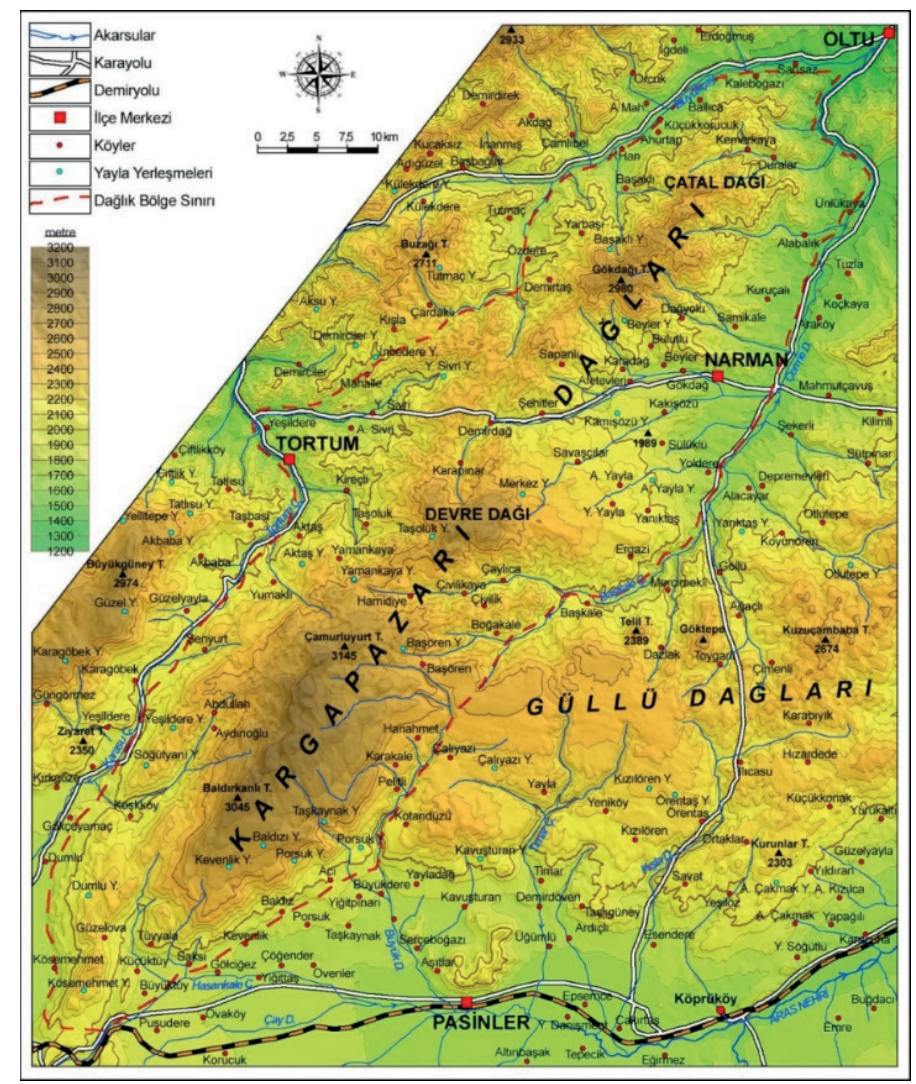

Şekil 2: Kargapazarı Dağları ve çevresinin fiziki haritası (HGM 1/100.000 Erzurum Paftaları)

Figure 2: Physicalmap of Kargapazarı Mountains and its surroundings (HGM 1 / 100.000 Erzurum Sections)

yapılmaktadır. Kargapazarı Dağları güneye doğru Erzurum ve Pasinler ovası arasında incelerek orta yükseklikte bir dağ eşiği halinde, Erzurum güneydoğusundaki Palandöken Dağları ile birleşmektedir (Saraçoğlu, 1989, 35-36). Kuzeydoğuda ise Erzurum-Kars Platosuna bağlanmaktadır.

Kargapazarı Dağları, Erzurum Ovası'nın kuzeydoğusundan başlayıp 30-35 km uzunluğunda, 8-10 km genişliğinde uzanmaktadır. Dağın kuzeybatıya doğru uzanan ince sırtları Erzurum Ovası ile Pasinler Ovası'nı birbirinden ayırmıştır.

Kargapazarı Dağları'nda en yüksek zirvenin yükseltisi 3288 $\mathrm{m}$ olup kuzeydoğuya doğru yükselti azalmaktadır. Dağın üzerinde ortalama $2500 \mathrm{~m}$ yükseltilerinde plato karakterinde belirgin geniş düzlükler yer almaktadır. Bu düzlüklerin de üzerinde yüksek zirvelerden oluşan ve birbirlerinden ayrılan üç farklı dağ yer almaktadır. Bunlardan kuzeybatı uçta yer alan Asıl Kargapazarı Dağı, ortada Devre Dağı ve kuzeydoğuda Çatal Dağı bulunmaktadır. Bazaltların yüzeylendiği alanlar çıplak olmakla birlikte geri kalan alanlar bahar mevsiminde çayır ve steplerle kaplıdır.
Araştırma sahası Türkiye'de kışların en sert geçtiği Kuzeydoğu Anadolu platolarına karşılık gelmektedir. Saha soğuk sert ve uzun kışlar ile don olayının uzun süre yaşandığı, yazları serin, asıl yağışlı mevsim ilkbahar olmakla birlikte, yaz ve güz aylarında da yağışın görüldüğü bir iklim tipine sahiptir. Orografik şartlara, karasallık derecesine ve coğrafi konuma bakılarak, sahanın iklimi her mevsim yağışlı Karadeniz ve Doğu Anadolu iklimi arasında bir geçiş tipidir diyebiliriz. Yıllık sicaklık ortalamaları Erzurum'da $5,5^{\circ} \mathrm{C}$, Tortum'da $8,3^{\circ} \mathrm{C}$ ve Oltu'da $9,95^{\circ} \mathrm{C}$ kadardır. En düşük sıcaklıklar $-5,5^{\circ} \mathrm{C}$ iken en yüksek sıcaklıklar $20,5^{\circ} \mathrm{C}$ dir. Bu yönüyle de yıllık sıcaklık fark1 yaklaşık $25^{\circ} \mathrm{C}$ civarındadır. Sicaklıklar kuzeydoğuya doğru gittikçe artmaktadır. Bu durum yükseltinin arttı̆̆ını ve Karadeniz Bölgesine yaklaşıldığını göstermektedir (Şekil 3).

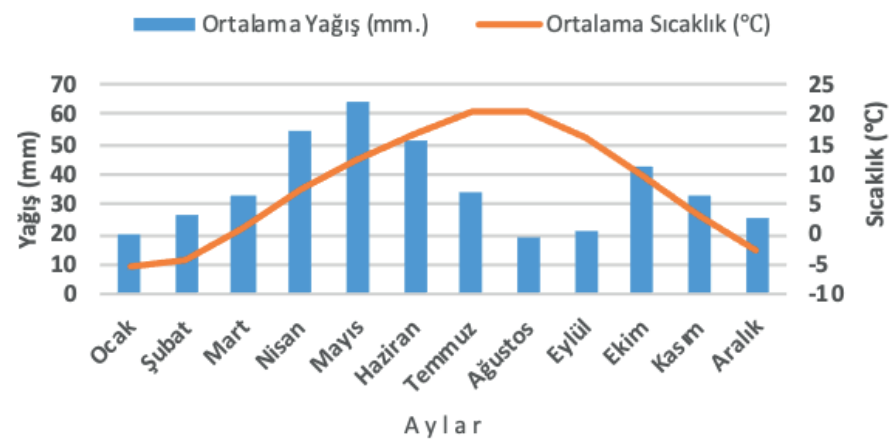

Şekil 3: Erzurum'da uzun yıllar sıcaklık- yağış değişim grafiği (M.G.M verileri)

Figure 3: Temperature and precipitation change graph of Erzurum formany years (M.G.M data)

Erzurum, Oltu ve Tortum meteoroloji istasyonlarının verilerine göre yağışın mevsimlere dağılışında en fazla yağış \%36 ile ilkbaharda düşerken ikinci en yağışlı mevsim \%24'lük oranla yaz mevsimine rastlamaktadır. Yazları yağışı karasal iklim, tipik olarak Doğu Anadolu'nun kuzeyinde (Erzurum-Kars ve Ardahan platolarında) görülür. Yaz yağışlarının fazla olması, Erzurum-Kars ve Ardahan platolarındaki çayırların yetişmesine ve ekonomik faaliyet olarak hayvancılığın ön plana çıkmasına imkan hazırlamıştır. Buralarda yaz yağışlarının fazla olmasının sebebi, şiddetli karasallık ve zaman zaman Karadeniz üzerinden gelen cephe sistemlerinin etkili olmasıdır. Yağışların \%23'ü sonbaharda ve \%17 si ise kış aylarına rastlamaktadır. Yaz yağışları kuzeydoğuda yer alan Oltu ve Tortum ilçelerinde daha da ön plana çıkmıştır. Erzurum'da yıllık yağış miktarı $411 \mathrm{~mm}$, Oltu'da 392 mm ve Tortum'da 467 mm ye çıkmaktadır.

Kısa mesafelerde yer şekillerinin farklılaşması, yüksek dă kütlelerinin varlığı, dağların uzanışı ve konum özelliğinden 
etkilenen hava kütleleri, kar yağışı görülme olasıllğını ve karın yerde kalma süresini şekillendirir (Yiğit, 2015: 134). Karla örtülü gün sayısı Erzurum'da 112, Tortum 83 ve Oltu'da 76 güne karşı1lık gelmektedir. Kar kalınlığ 1 Erzurum'da $110 \mathrm{~cm}$, Tortum'da 95 cm ve Oltu'da 61 cm'dir. Kar örtüsü Erzurum'da Haziran ve Eylül arası dönemde ortadan kalkmaktadır. Karla örtülü gün sayısı kuzeydoğuya doğru gidildikçe azalmaktadır. $\mathrm{Bu}$ durumunda yine geçiş alanına karşılık gelmesiyle bağlantılıdır.

Kargapazarı Dağları bazalt ve andezitlerden oluştuğu için akarsular tarafından fazla yarılmamıştır. Kütlevi bir özellik göstermesi ve üç farklı zirveden oluşması nedeniyle drenaj ağı 1şınsaldır. Bu dağlık kütleden kaynaklanan akarsular üç farklı havzaya dökülmektedir. Bu özelliği nedeniyle hidrografya bakımından adeta bir çatı konumundadır. Dağın güneydoğu bölümünün suları Hasankale Çayı vasıtası ile Aras Nehrine dahil olup Hazar Denizine, kuzey bölümünün suları Çoruh nehrinin kolları Tortum ve Oltu çayı vasıtası ile Karadeniz'e ve güneybatı bölümünün suları da Karasu nehri aracılığıla Fırat Nehrine karışarak Basra Körfezi'ne taşınmaktadır. İklim özelliklerine bağlı olarak kış mevsiminde akarsuların debileri minimum, yaz başlarında ise maksimum seviyeye çıkmaktadır. Dağlık alan üzerinde çok sayıda kaynak suyunun varlığı ve bunların kar suyu ile beslenmesi yanında doğal göllerin bulunması yaz mevsiminde yaylacılık için önemlidir.

Kargapazarı Dağlık Ünitesinde yüksek plato stepleri yaylacılık faaliyetlerinin yoğunluk kazandığı sahalar olarak karşımıza çıkmaktadır. Kışları şiddetli ve uzun geçen, daha elverişli nemlilik şartlarına ve serin bir yaz mevsimine sahip olan bu sahalarda, asıl steplerden çok daha farklı bir manzarayla karşılaşı1ır. Ot formasyonları elverişli bir yerleşme ortamı bulduğu için daha sık ve uzun boylu, her zaman yeşilliğini muhafaza eden bir örtü oluşturmaktadır. Yüksek plato steplerinin üzerinde ise, daha yüksek yerlerin ot formasyonları olan Alpin çayırlar yer almaktadır (Sözer, 1972: 16). Kargapazarı dağları ve çevresinde bitki örtüsünün dağılımı üç grup halinde ele alınır. İran-Turan fitocoğrafyasına sahip alanda Alp, Orman ve sucul vejetasyon olarak incelenir. Alpinikvejatasyon araştırma alanının en geniş sahasını kapsar. 2000-3000 m'ler arasındaki yaylalarda görülür. Yerleşim merkezleri ve çayırlar 2000 m’ye kadar dağılış gösterir.

Erzurum ilinde toplam 15.929.630 dekarlık çayır ve mera arazisi yer almaktadır. Arazi kullanım sınıfları içerisinde \% 72 'lik bir orana karşılık gelen çayır ve mera alanları Kargapazarı dağlık kütlesinde $\% 51^{\prime}$ lik bir oranla diğer arazi kullanım türleri

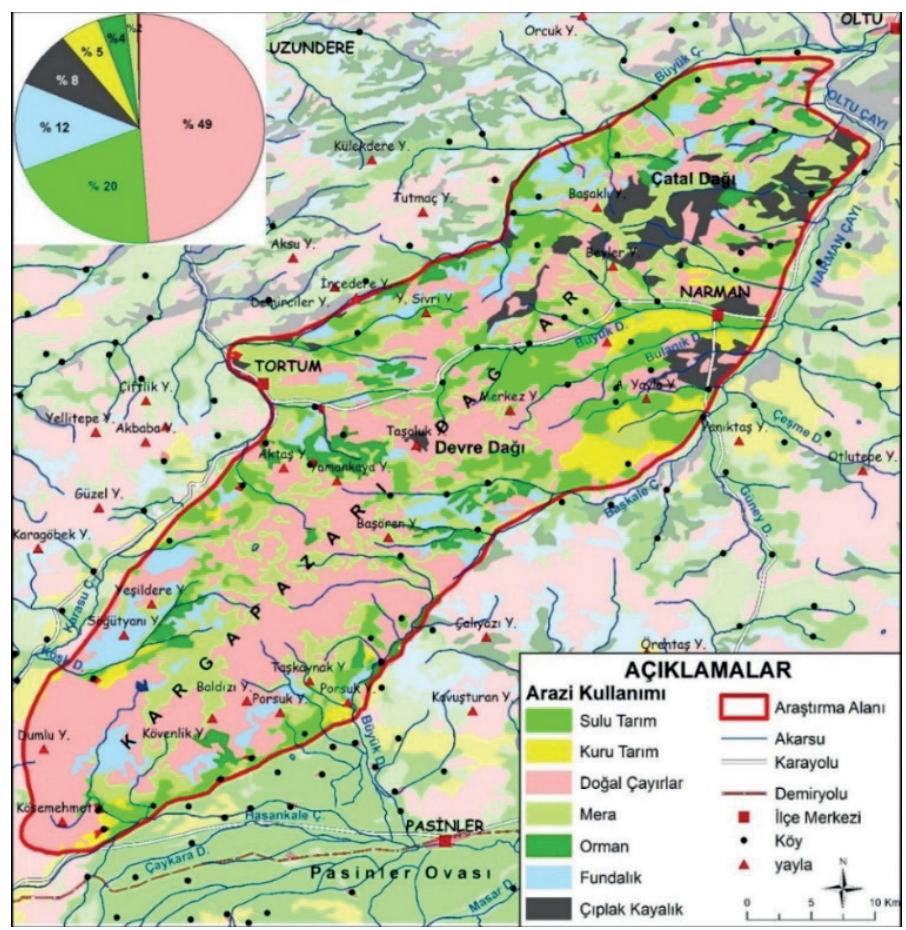

Şekil 4: Kargapazarı Dağları ve Çevresinin arazi kullanım durumu (Corine 2012-Erzurum ili arazi varlığı 1980)

Figure 4: Land usestatus of the Kargapazarı Mountains and its surroundings (Corine 2012- land size of Erzurum province 1980)

içerisinde ilk sırada yer almaktadır. İlçeler bazında değerlendirildiğinde çayır ve mera alanlarının \%37'lik bir oranla (896.644 dekar) en fazla olduğu ilçe Tortum'dur.

Çayır ve mera arazileri oranı araştırma sahasında bulunan ilçe toplamlarında Pasinler ilçesi \%22 (547.050 dekar), Yakutiye \%21 (508.051) ve Narman \%20'lik (480.200 dekar) değerlere karşılık gelmektedir. Bu değerlerle dört ilçenin çayır ve mera oranı Erzurum ilinin \%15'ini karşılar (Şekil 4). Arazi kullanımının yarısından fazlası başta doğal çayırlar olmak üzere çayır ve mera alanlarından oluşmaktadır. Bu özellik bu alanlarda yaylacılık faaliyetinin önemini zaten vurgulamaktadır. $\mathrm{Bu}$ saha mera alanından ziyade doğal çayırların varlığı ile yaylacılık ekonomisinin kaynak noktalarından birine karşılık gelmektedir.

\subsection{Beşerî ve Ekonomik Coğrafya Özellikleri}

Türkiye'de kır yerleşme tiplerinin oluşmasında, nüfusun dağılişında ve ekonomik faaliyetlerin şekillenmesinde yeryüzü şekilleri, yükselti ve iklim önemli ölçüde rol oynarlar. Tarihsel gelişim içinde fiziki etmenlerin yanı sıra yerine göre sosyal ve kültürel faktörlerde bu hayat tarzının şekillenmesinde etkili olabilirler (Emiroğlu, 1974: 25). 
1980 y1lı nüfus özellikleri incelendiğinde kırsal nüfus, Türkiye genelinde olduğu gibi araştırma sahasında da şehirsel nüfustan fazladır. Dağlık ünite ve çevresinde idari konumda bulunan Narman (4.596 şehir-20.576 kır nüfusu), Tortum (4.315 şehir-41.434 kır nüfusu) Oltu (12.351 şehir-28.629 kır nüfusu) ve Pasinler (19.752 şehir-42.232 kır nüfusu) ilçelerinde şehir nüfusu kır nüfusunun gerisinde kalmıştır.

1990 yılına gelindiğinde ise araştırma sahasında kır nüfusunun azalmış ve şehir nüfus artmıştır. Kırsal nüfusun azalması şehir merkezlerine de nicelik olarak yansımadığından bu alanın ciddi bir oranda göç verdiğini söyleyebiliriz. Toplam nüfus açısından değerlendirildiğinde 2000-2018 yılları arasında Narman'da \%52, Tortum'da \%56, Oltu'da \%20 ve Pasinler'de ise $\% 35$ oranında nüfus azalışı gerçekleşmiştir.

1980 yılında araştırma sahasında yer alan köylerin toplam nüfusu 29.747 kişi iken 1990 yılında 27.547 kişi, 2000 yılında 23.506 kişi, 2010 yılında 17.667 kişi ve 2018 yılında ise 15.468 kişidir. Bu değerlerde göstermektedir ki Kargapazarı morfolojik ünitesi üzerinde yer alan köy yerleşmeleri geçmişten günümüze sürekli nüfus kaybetmektedir. 1980-2018 yılında $\% 48$ oranında kırsal nüfusta azalma görülmektedir. 2018 yılında kırsal alanlarda nüfus azalırken ilçe merkezleri nüfusun kümelendiği sahalara karş1lık gelmektedir (Şekil 5).

1997 yılında, yapılan bir köy envanteri çalışmasının sonuçlarına göre, Türkiye'de yaylaya çıkan köy sayısı 7000 civarındadır. Kırdan şehirlere yönelik göçlerin etkisiyle yaylaların kullanımında belirgin bir azalmadan, yaylacılı̆̆ın ve yaylaların terk edildiğinden söz etmek mümkündür. $\mathrm{O}$ halde geçmişten günümüze doğru sayıları azalmış olmakla birlikte, köylerimizin \%20 kadarı hala aktif olarak yaylaları kullanmaya devam etmektedirler (Yiğit 2015: 142).

Erzurum-Kars Bölümünde kır yerleşmeleri genel olarak depresyon tabanlarında toplanmıştır. Ancak akarsularla yarılmış taşkın riskinin olduğu sahalarda köyler depresyon kenarlarından alüvyal yelpazelere doğru şekillenmişlerdir. Taşkın riskinin olmadığı sahalarda ise köyler genellikle en alçak sahalarda kurulmuş ve hatta akarsular tarafindan yarılmışsa vadilerin tabanlarına veya yamaçlarına doğru kurulmuşlardır (Erinç 1953: 98).

Erzurum'da kırsal yerleşme ve nüfus ile ilgili yapılmış çalışmalarda genellikle yerleşme tipi (kom, mezra, köy), mesken tipleri ve nüfus hareketleri ile ilgili ayrıntılı literatüre rastlamak mümkündür (Özav 1991, Özav 1994, Özav 1995, Y1lmaz 1991 a, Yılmaz 1991 b, Yılmaz 1991 c, Özey 1985, Özey 1987, Özey 1990, Yüksek 2002).

Erzurum ilinde kırsal yerleşmelerin dağılımına baktığımız zaman en fazla ünite köy yerleşmelerinde karşımıza çıkmaktadır. Toplam 1.093 köy yerleşmesi yer almaktadır. Bu yerleşmeleri 537 yerleşme ile mezra-mahalle yerleşmeleri takip ederken 420 yayla yerleşmesi ve 125 de kom yerleşmesi yer almaktadır. Yerleşme tipleri içerisinde yükseltisi en az olan üniteler köy ve mezra yerleşmelerinden oluşmaktadır. Erzurum'da köylerin 1000'e yakını 1500 m'nin üzerindeki yükseltilerde kurulmuştur. Erzurum'da toplam 537 mahalle-mezra yerleşmesi yer almaktadır. Mezra yerleşmeleri yoğun olarak engebeli alanlarda kurulmuştur. 2000 metrenin üzerinde 150 tane yerleşme bulunmaktadır.

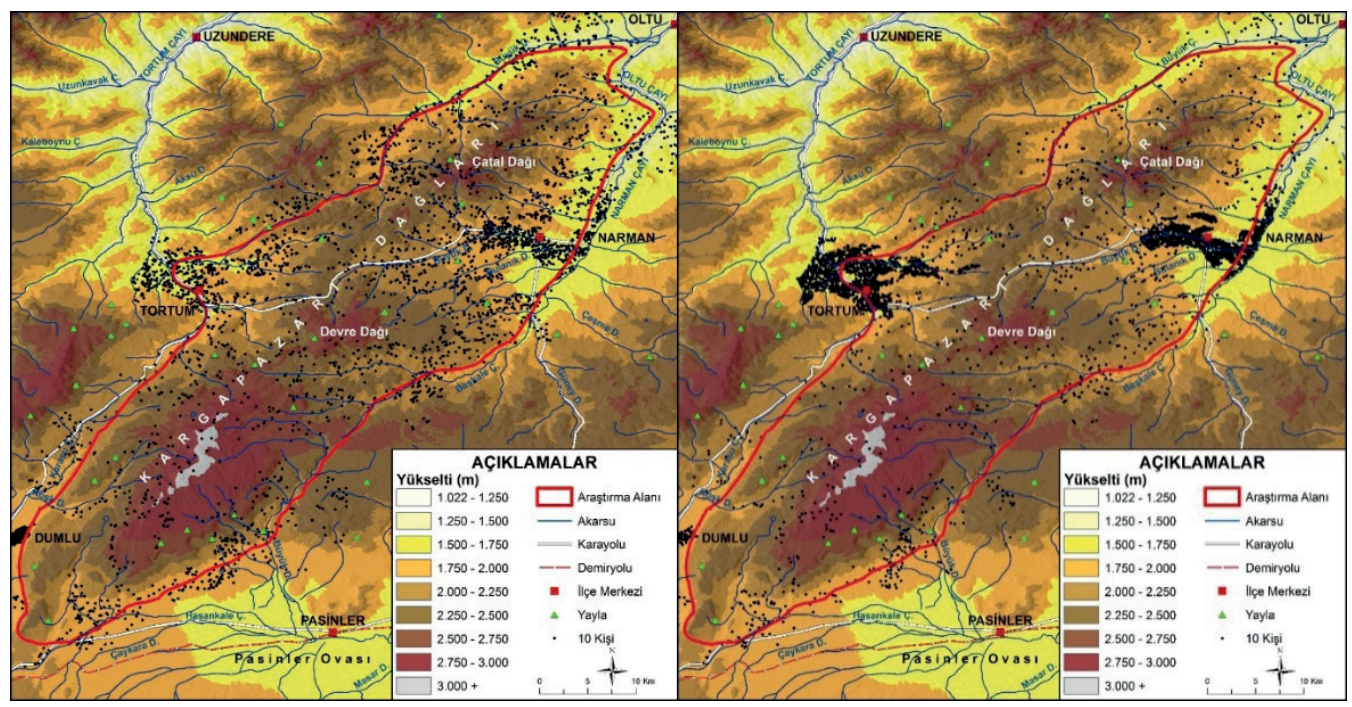

Şekil 5: Kargapazarı Dağları ve çevresindeki Nüfus dağılışı (1980-2018 TÜiK nüfus istatistikleri)

Figure 5: Population distribution around Kargapazarı Mountains and its surroundings (1980-2018 TUIK population statistics) 
Komlar esas amacı hayvancılık yapmak için kurulmuş ve yaylalardakinin aksine yaz aylarında terkedilen küçük ve geçici bir yerleşme tipidir. Kış başında hayvanlar yayladan koma inerler ve bu devreyi komda geçirirler. Bunun yanı sıra bütün yıl yerleşilen komlarda vardır. Kuruluş yeri açısından genellikle eğimin arttı̆̆g yerlerde komlar ön plana çıkmaktadır (Tunçdilek, 1967). Erzurum ilinde komlar daha çok sürekli yerleşme alanı olarak kullanılır ve şahısların isimleri ile anılırlar ve ismini kurucusundan alırlar. Yine bazı komlar örneğin Yakutiye ilçesine bağlı Şehitler komu günümüzde bir köy yerleşmesine dönüşmüştür (Koday, 1999: 360).Komların yoğunluk gösterdiği yükseltiler genellikle 2000 m'nin üzerindedir. $2000 \mathrm{~m}$ ve üzeri 71 kom yerleşmesi vardır. Kom yerleşmeleri daha çok Erzurum ili güney-güneydoğu kesiminde Karasu-Aras sıradağlarının uzandığ1 sahalarda 3000 m'yi bulan yükseltilerde yoğunluk göstermektedir. Komlardaki yerleşme özelliği genellikle dokusal açıdan dağınık bir özellik göstermektedir. Bu durum yer şekilleri ve hidrografyadan kaynaklanmaktadır (Şekil 6).

Doğu Anadolu Bölgesinin kuzeydoğu kesiminde yaz mevsiminin nemli ve serin geçmesi hayvancılık için önemli bir ortam oluşturmaktadır. Burada ilkbahar sonunda başlayan ve yaz mevsimi boyunca devam eden yaz yağışları çayır nitelikli ot topluluklarının oluşmasını sağlamaktadır. Bölgenin diğer alanlarında bulunmayan geniş otlak alanlarına dayalı olarak da hayvancılık yoğun bir şekilde yapılmaktadır (Arınç, 2011: 82).

Erzurum ili genelinde yıllara göre küçükbaş hayvan varlığ1 değişim grafiğine baktığımızda 23 yıllık periyotta hayvan sayısında $\% 50$ oranında bir azalma yaşanmıştır. Küçükbaş hayvan sayısında azalmanın en belirgin olduğu dönem 19952009 yılları arasıdır. Bu dönemde \%73 oranında bir azalış söz konusudur. Hayvan türleri açısından değerlendirildiğinde azalmanın koyun yetiştiriciliğinde daha bariz olduğu gözlemlenmiştir. 1995-2009 yılları arasında koyun sayısında $\% 74$ k1l keçisi sayısında \%61 oranlarında azalışlar gözlemlenmiştir. 2009 yılı bilindiği üzere Ülkemizin birçok alanında özellikle de Doğu ve Güneydoğu Anadolu bölgelerinde çayır ve mera alanları ile yaylaya çıkışların güvenlik nedeniyle yasaklandığı dönemdir. Erzurum ve çevresi de güvenlik sebebiyle yayla yasakları kapsamında değerlendirilmiş bu olayda özellikle küçükbaş hayvan sayısında azalmaya neden olmuştur. 1995-2018 yıllarını kapsayan 23 yıllık dönemde koyun yetiştiriciliğinde \%53, kıl keçisi yetiştiriciliğinde ise \%13'lük bir azalış görülmektedir. 2009-2018 yılları arasında koyun sayısında \%81, kı1 keçisinde ise \%121 oranında artış gözlemlenmiştir (Şekil 7). Özellikle ülkemizde hayvan sayısının azalışı hayvancılığa duyulan ihtiyaçla beraber 2009 yılından

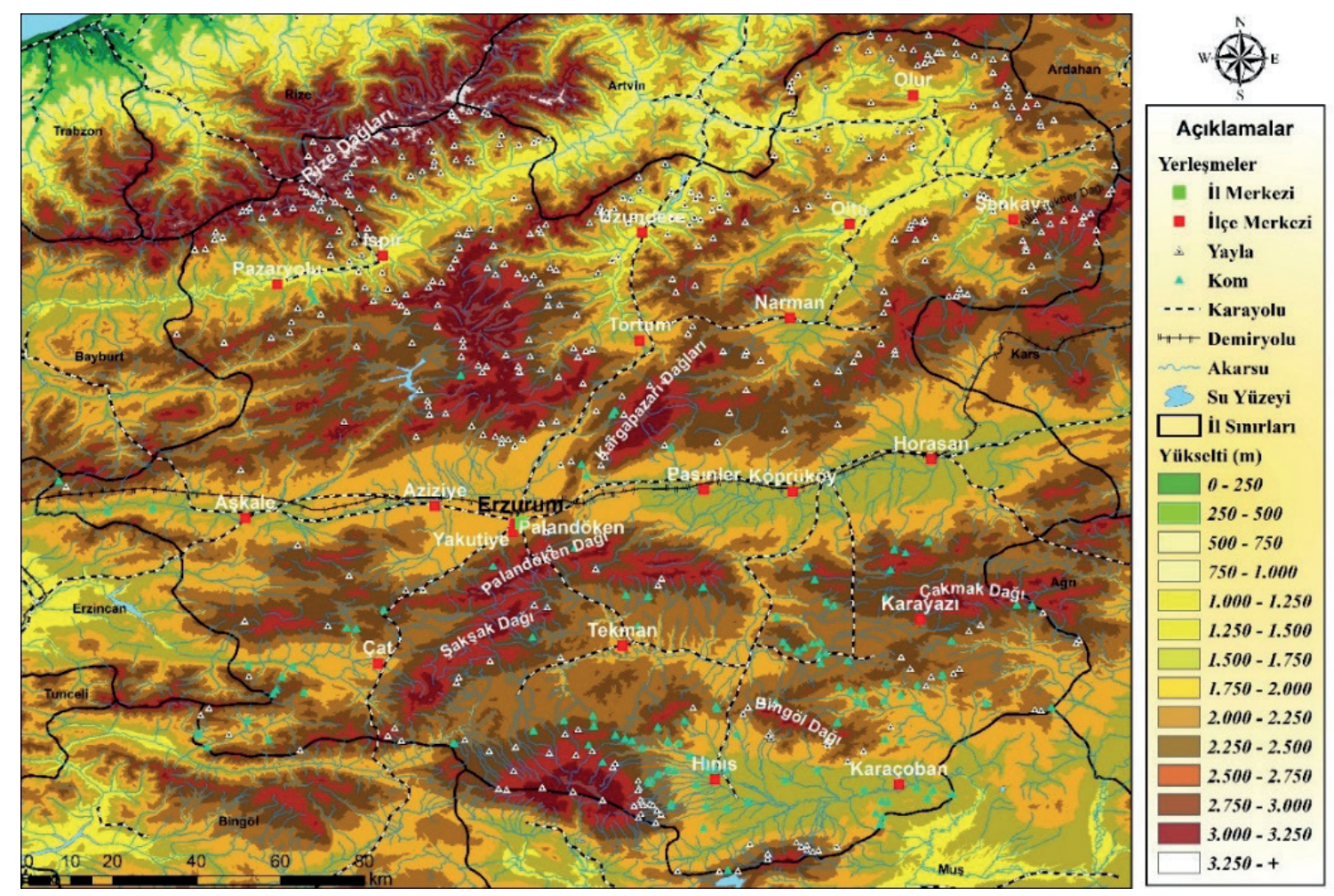

Şekil 6: Erzurum ilinde yayla ve komların dağılışı (HGM 1/100.000 ölçekli Erzurum paftaları)

Figure 6: The distribution of high lands and mountain houses in the Erzurum province (HGM 1/ 100,000 scale Erzurum Sections) 
sonra teşvik ve hibe dönemi ile birlikte tekrar sayısal anlamda hayvan sayısı artmaya başlamıştır. Buna rağmen hayvancılık ile ilgili sorunlar hala devam etmektedir.

Araştırma sahasına dahil Pasinler (63.635 baş), Yakutiye (34.448), Tortum (32.811), Oltu (29.190) ve Narman ilçesi (6.409 baş) koyun varlığı açısından ilde çok fazla önem arz etmemektedir. Sadece Pasinler ilçesi sahip olduğu geniş plato alanları sayesinde mera hayvancılığına yönelik ekonomik faaliyet yürütmektedir (Şekil 8).

Kargapazarı dağlık ünitesi üzerinde yer alan köylerin küçükbaş hayvan varlığına baktığımızda Pasinler ilçesinde yer alan köy yerleşmeleri ilçenin koyun varlığının \%27'sine (17.325 baş) karşılık gelmektedir. Koyun varlığı açısından Yakutiye \%50
(18.775 baş), Tortum \%13 (4.334 baş), Oltu \%6 (1.665 baş) ve Narman'da \%59 (3.775 baş)'nu karşılamaktadır. Kargapazarı yaylalarında ilçelere göre koyun yetiştiriciliğinde bu sahadan yararlanma oranları ise şöyle sıralanmaktadır. Yakutiye \%41, Pasinler $\% 38$, Tortum \%9, Narman $\% 8$ ve Oltu \%4’tür.

Erzurum ilinde, 1995-2018 yılları arasında toplam sığır yetiştiriciliği \%32 oranında artış kaydetmiştir. 1995 yılında toplam sığır sayısı 582.680 baş iken 2018 yılında 767.112 başa yükselmiştir. 2009 yılından sonra Gıda Tarım İl Müdürlükleri tarafından özellikle melez ve kültür sığır yetiştiriciliğine verilen desteklerin fazlalığı ile birlikte hayvan sayılarında da artışlar olmuştur.

Sığır türlerine göre değerlendirdiğimizde Erzurum ili genelinde yerli sığır yetiştiriciliği 1995-2018 yılları arasında

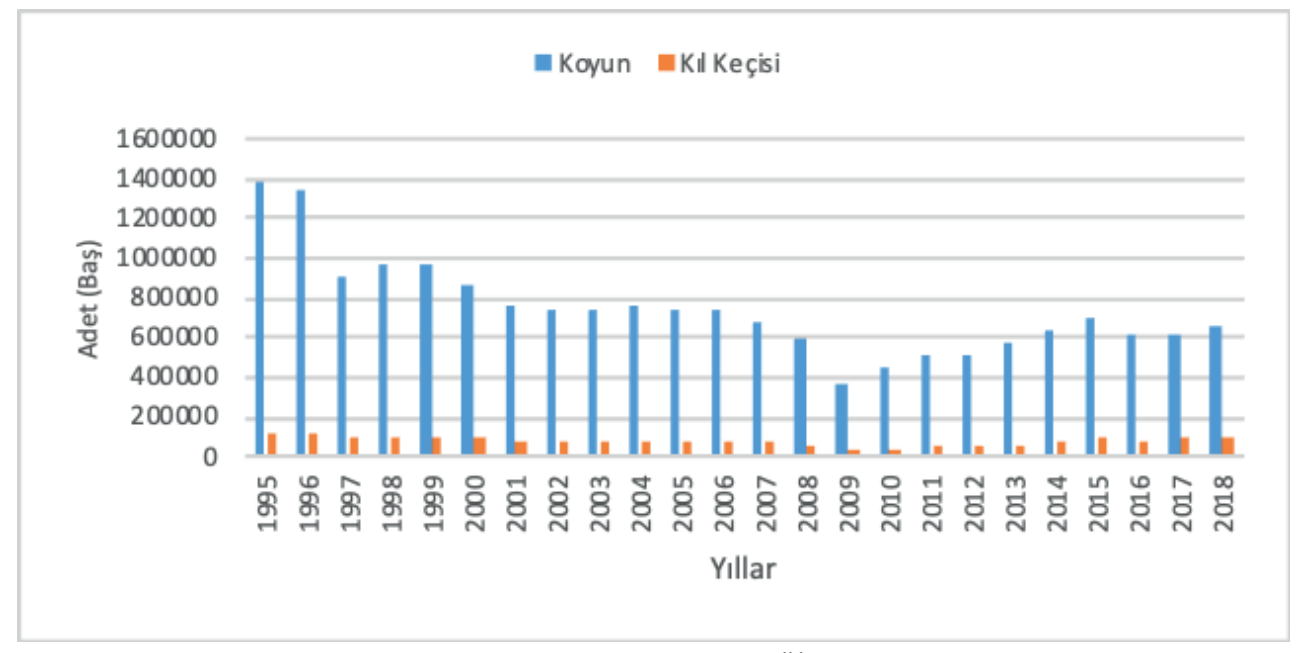

Şekil 7: Erzurum'da Yıllara göre küçükbaş Hayvan varlığı (TÜiK 1995-2018 Hayvancılık istatistikleri) Figure 7: The number of small cattle in Erzurum by years (TUIK 1995-2018 Live stock statistics)

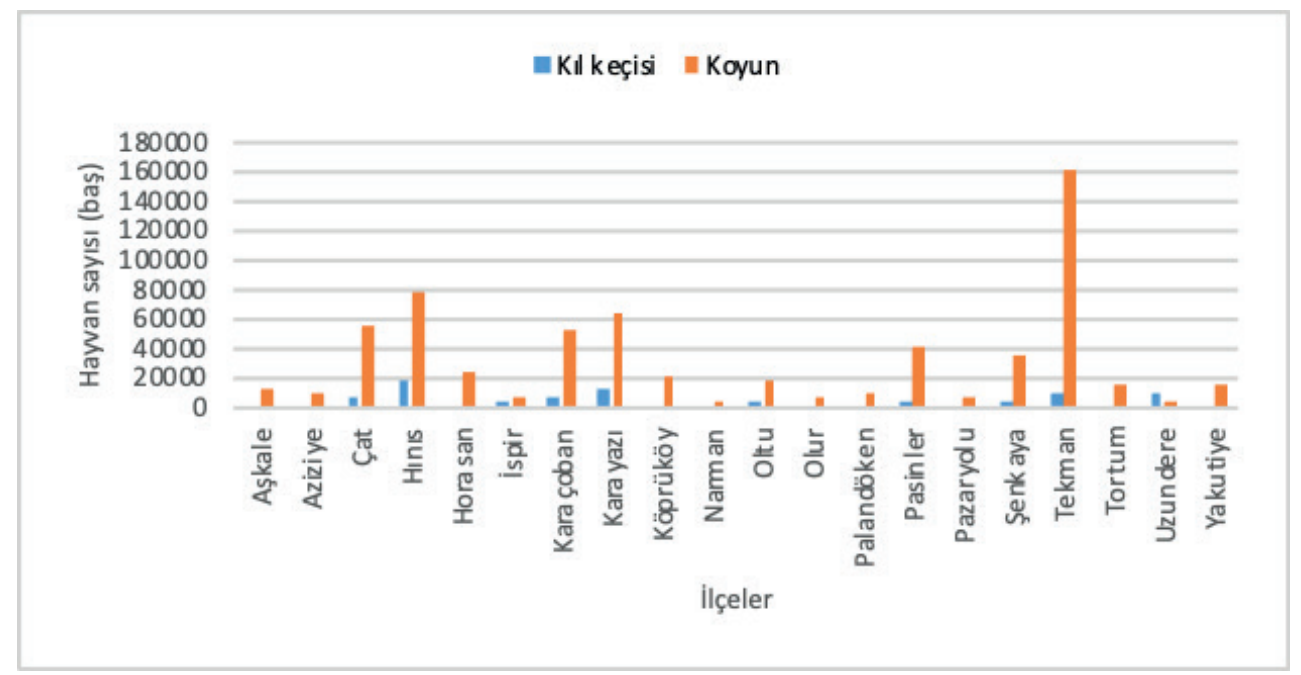

Şekil 8: Erzurum ve ilçelerinde küçükbaş hayvan varlığı.

Figure 8: The number of small cattle in Erzurum and its districts. 
\%91 oranında azalma göstermiştir. Yerli sığırda görülen azalma kültür sığır yetiştiriciliğinde artış şeklinde gözlemlenmiştir. Kültür sığır yetiştiriciliğinde 1995-2018 yılları arasındaki dönemde \%661 oranında artış olmuştur (Şekil 9). Kültür sığır yetiştiriciliği gibi melez sı̆̆ır sayısında da 1995-2018 yılları arasında \%346 oranında artışlar görülmektedir. 1995 yılında sığır türleri kendi içinde \%74 yerli, \%23 melez ve \%3 kültür sığırından oluşurken 2018 yılında \%76 melez, \%19 kültür ve \%5 oranında da yerli sığır yetiştiriciliği şeklinde gerçekleşmiştir.

Erzurum ilinde ilçelere göre sığır varlı̆̆ını değerlendirdiğimizde özellikle coğrafi anlamda Karadeniz bölgesinin Doğu Karadeniz bölümüne dahil olan kuzey kesimlerinde sığır yetiştiriciliğinin geniş çayır alanlarının varlığına bağlı olarak küçükbaş hayvancılıktan daha ön planda yer aldığını görmekteyiz. Otlakların varlığına bağlı olarak ülkemiz hayvancılığının temel sorunlarından biri olan yem bitkisi masrafının olmaması bu alandaki yaylacılık faaliyetlerini önemli kılmıştır. Pasinler ilçesi sığır türlerinin toplamı bakımından (93.207 baş) ilde en ön plana çıkan yerleşmedir. Yakutiye (59.024 baş) ilçesi ile kuzeyde yer alan Narman (54.943 baş), Tortum (41.873 baş) ve Oltu (32.002 baş) ilçeleri küçükbaş hayvancılıktan ziyade sığır yetiştiriciliğinin daha ön planda olduğu ilçelerdir (Şekil 10).

Kargapazarı dağlık ünitesine dahil köy yerleşmelerinin sığır sayısı incelendiğinde Pasinler ilçe toplamının \%30’unu (27.717 baş), Narman \%45'ini (24.944 baş), Yakutiye \%25'ini (15.013 baş), Tortum \%25'ini (10.321 baş) ve Oltu ise \%13'nü (4182) araştırma sahasında beslemektedir. $\mathrm{Bu}$ sahalarda geniş çayır-

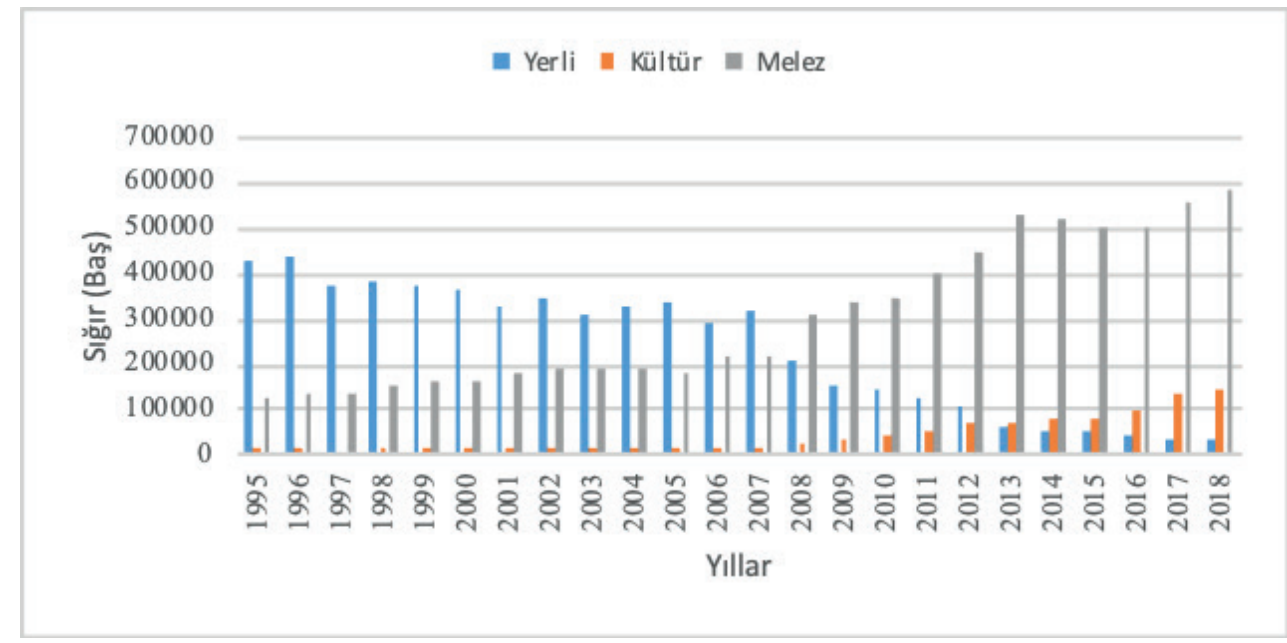

Şekil 9: Erzurum'da yıllara göre sığır yetiştiriciliği.

Figure 9: Cattle breeding in Erzurum by years.

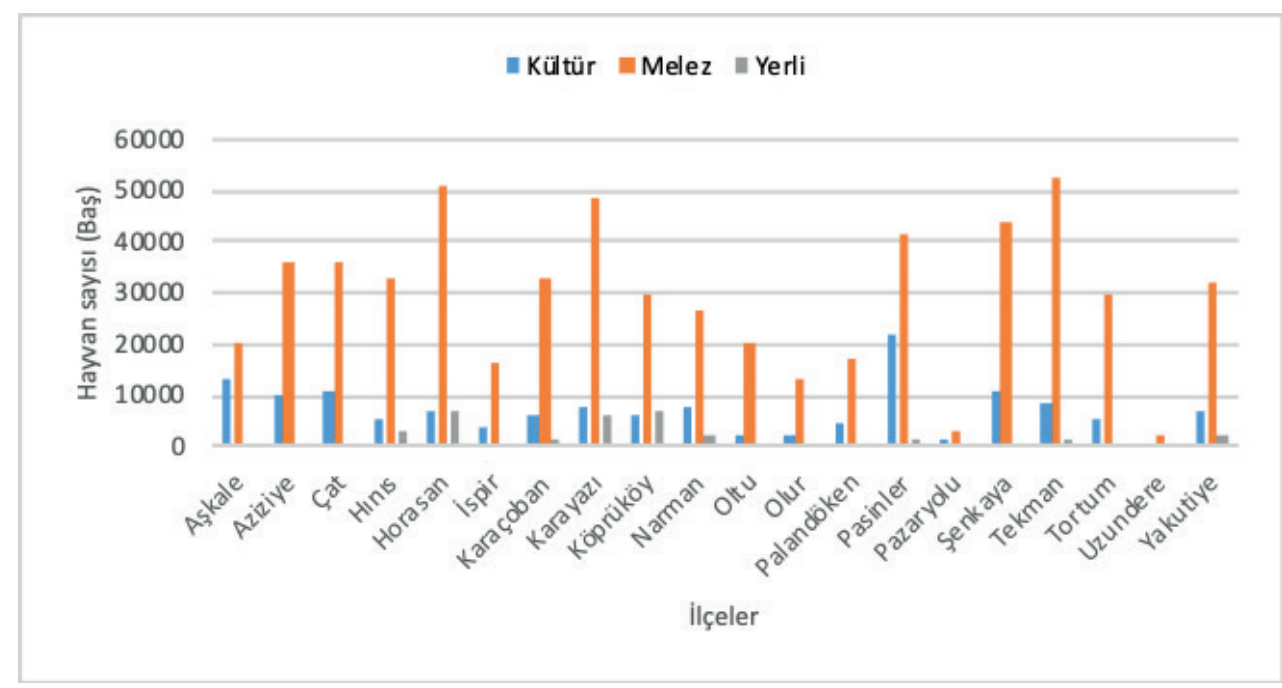

Şekil 10: Erzurum ve ilçelerinde sığır türlerinin varlığı.

Figure 10: Number of cattle species in Erzurum and its districts. 
mera alanlarının ve yaylaların varlığı bu ekonomik faaliyetin yürütülmesinde etkendir. Kargapazarı dağlık ünitesinde sığır yetiştiriciliği ilçeler bazında ele alındığında Pasinler ilçesi \%34'lük oranla bu sahadan yararlanma bakımından ilk sırada yer almaktadır. İlçeyi sırasıyla Narman \%30, Yakutiye \%18, Tortum $\% 13$ ve Oltu $\% 5$ oranında izlemektedir.

\section{AMAÇ VE YÖNTEM}

\subsection{Amaç}

Türkiye'de hayvancılık faaliyetleri geçmişten günümüze sürekli olarak sorunlarla karşılaşmaktadır. Mera alanlarının daraltılması hayvan sayılarında düşüşlere neden olurken diğer yandan da dönem dönem güvenlik problemlerine bağlı olarak yaylalara çıkışların yasaklanması hayvancılığı olumsuz yönden etkilemektedir. Bu çalışmada özellikle hayvancılık bölgesi olarak anılan DoğuAnadolu Bölgesi'ndeyaylacılık potansiyelinin yeterince değerlendirilememesi problem durumu olarak ele alınmıştır. Yaylacılık çalışmaları, son yıllarda daha çok değişen fonksiyonel özellikler açısından değerlendirilmekte ve alternatif turizm açısından ele alınmaktadır. Kargapazarı dağları, Kuzeydoğu Anadolu'da önemli yayla potansiyeline sahip olmakla birlikte çalışılmamış bir alan olduğu için tercih edilmiş̦tir.

\subsection{Metot ve Malzeme}

Kargapazarı yaylaları ile ilgili çalışmada Erzurum, Pasinler, Narman, Oltu ve Yakutiye Tarım Müdürlüklerinden alınan veriler, köy muhtarlarıyla yapılan görüşmeler ve saha çalışmaları ile birlikte TÜIK nüfus ve hayvancılık istatistiklerinden faydalanılmıştır. ArcGIS 10.4. ve Excel programları birlikte kullanılarak Erzurum ilinde yerleşme tipleri 1/100.000 ölçekli 21 topografya haritası taranarak yükselti basamaklarına göre sınıflandırılmıştır. Daha sonra alanın arazi kullanımı haritası Corine 2012 verileri ve köy hizmetlerinin Erzurum ili arazi varlığı haritaları birlikte değerlendirilerek üretilmiş̧ir. Oluşturulan topografya, arazi kullanım ve yaylacılık haritaları yorumlanarak sahanın yaylacılık potansiyeli belirlenmiştir. Yaylacılığın doğal ve beşeri şartlarla ilişkisini kurmak için iklim, nüfus, hayvancılık ve yerleşme verileri kullanılarak ilişkisel yorumlar yapılmıştır. Kargapazarı yaylaları ele alınırken saha ve doküman analizinden faydalanılmıştır.

\section{YAYLACILIK FAALIYETLERI}

Doğu Anadolu Bölgesinde Erzurum-Kars Bölümü yaylacılığın gelişmiş olduğu bir sahadır. Özellikle Karasu-Aras Dağları ile Yukarı Murat-Van Bölümü Yaylaları önemlidir. Erzurum-Kars Bölümünde özellikle Güllü ve Allahuekber
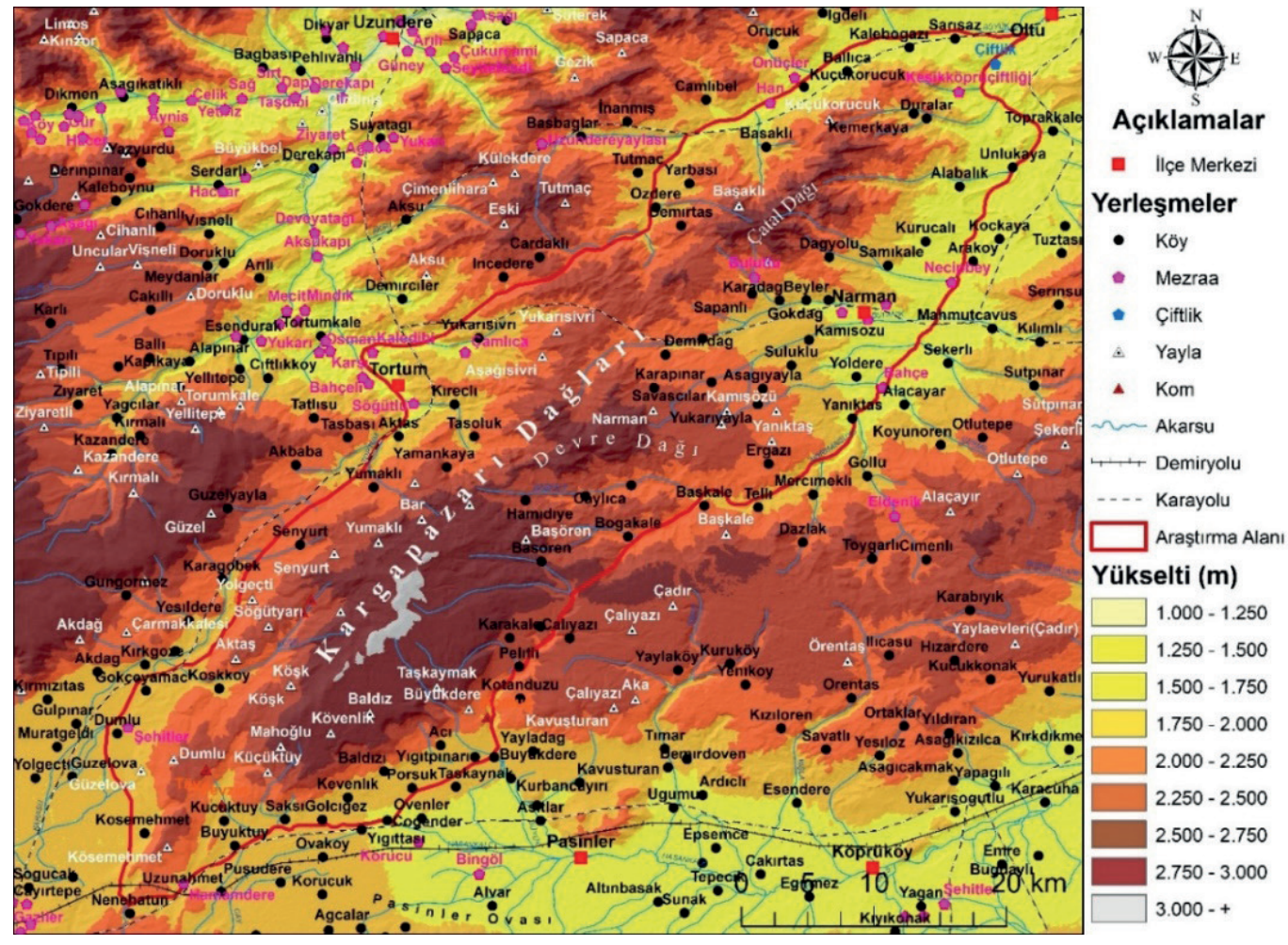

Şekil 11: Kargapazarı dağlık ünitesi ve çevresinde kırsal yerleşmelerin dağılışı (HGM 1/100.000 ölçekli Erzurum paftaları).

Figure 11: Distribution of rural settlements in the Kargapazarı mountainous unit and its surroundings (HGM 1 / 100,000 scale Erzurum Sections). 
Dağları ile Karasu-Aras dağlarının yüksek platoları yayla yerleşmelerinin ve yaylacılık faaliyetlerinin yoğunluk kazandığ bir bölgedir (Doğanay-Orhan, 2016: 316).

Erzurum ilinin toplam alanının \%32'si platolardan oluşmuştur. Bu platolar üzerinde hayvancılık faaliyetlerinin son derece önemli olduğu geniş yaylalar vardır. Bu yüksek düzlükler iklim, toprak ve bitki örtüsü itibariyle yüksek bir otlatma potansiyeline sahiptir. Yaylalar genellikle toprak tabakasıyla kaplı olup yaz aylarında yağan düzenli yağmurlar nedeniyle zengin bir ot örtüsü bulunur (Koday, 2005: 150). Kargapazarı yaylaları ise Çoruh-Kelkit sıradağlarının üzerinde yer alan geniş plato alanlarına karşıllk gelirken ilin kuzeydoğusunda yer almaktadır. Bu dağlık ünitede Narman, Pasinler, Tortum, Oltu ve Yakutiyeilçelerine ait toplam 84 köy bu alandan faydalanmaktadır. Ağırlıklı olarak Pasinler ve Narman ilçeleri ve bağlı köyleri bu yayla alanını kullanmaktadır (Şekil 11).

Kargapazarı Dağlık Kütlesinde ilçe merkezleri ortalama 1650 m yükseltide yer alırken köyler $1900 \mathrm{~m}$ civarındadır. Mezra yerleşmeleri 1700 m'lerde, yaylacılık faaliyetleri için önemli olan kom yerleşmeleri ise ortalama 2100 m olup yaylalarda 2400 m'lere kadar çıkmaktadır. En düşük yükseltideki köy yerleşmesi ile en yüksek yayla yerleşmesi arasında yaklaşık 1400 m'lik bir yükselti farkı bulunmaktadır. Yükseltisi en az olan yayla yerleşmesi (Güzelova) ile en fazla olan yayla (Baldızı) arasında yaklaşık 825 m'lik bir yükselti farkı vardır. Dağlık kütle üzerindeki yayla yerleşmelerinin yükseltileri kuzeydoğuya doğru azalmaktadır. Asıl Kargapazarı kütlesi ve Devre Dağı civarında bulunan yaylaların yükseltileri 2200 m'nin üzerinden başlayarak 2700 m'lere kadar çıkmaktadır. Bu alandaki yaylalar aynı zamanda bağlı bulundukları köylerin isimleriyle de anılmaktadir.

İlçeler bazında değerlendirdiğimiz zaman Pasinler ilçesi 17 köy yerleşmesi ve 15 yayla yerleşmesiyle Kargapazarı dağlarının yaylacılık açısından en hareketli alanına karşılık gelmektedir. Pasinler ovasının kuzeydoğu ucundan başlayan Kargapazarı morfolojik ünitesi, Oltu Çayı havzasına kadar uzanmaktadır (Şekil 12). Ünitenin güneydoğusunda yer alan Pasinler ilçesi yaylalarının ortalama yükseltileri 2300 m'nin üzerindedir. En düşük yükseltiye sahip yayla yerleşmesi 2205 m ile Büyükdere yaylası olurken en fazla yükseltiye sahip yayla yerleşmesi ise Mahoğlu (2360 m) yaylasıdır. İlçede toplam 54.670 büyükbaş ve 33.646 küçükbaş hayvan varlığı bulunmaktadır. Tımar ve Büyükdere köylerine ait Gülyurt, Zendo ve Tımar yaylaları yaklaşık $2300 \mathrm{~m}$ yükseltide olup plato sahasında yer almaktadır. Bu yaylalar, Kargapazarı dağlık kütlesi üzerinde göçer gruplar tarafından en çok tercih edilen sahalara karşılık gelir. Bu yaylalarda Tımar köyünde 1.690 Büyükdere köyünde ise 1900 hektarlık bir alan il dışından gelen yaylacılara kiralanmaktadır. Göçer gruplar 10 Mayıs'ta bu alana gelip 20 Eylül'e kadar yaylacılık aktivitelerini sürdürmektedirler. Pasinler ilçesinde Çilgöl (3700 dekar) ve Çingene (3000 dekar) yaylalarına da 15 aile ve 3000'nin üzerinde küçükbaş hayvan çıkartılmaktadır. Bunun dışında ilçede Gölceğiz, Pusudere, Yiğittaşı ve Yiğitpınarı köyleri bulundukları yükselti kuşağı (1700-1800 m) nedeniyle geniş mera alanlarına sahip olup büyükbaş hayvancıllğa yönelik yaylacılık faaliyetleri yürütülmektedir. Bu sahada kar örtüsünün varlığına bağlı olarak yaylacılık tarihleri de değişmektedir. Pasinler ilçesi yaylaları nispeten daha yüksek plato sahalarına karşılık geldiği için kar örtüsü daha geç yerden kalkmaktadır. Yüksek ve alçak plato sahalarındaki yaylacılık faaliyetleri arasında bir ay fark bulunmaktadır.

Narman ilçesinde toplam 480.200 dekarlık çayır ve mera alanı bulunurken toplam 29.479 büyükbaş, 2700 küçükbaş hayvan yer almaktadır. Narman ilçesi il dışından yaylacı grupları kabul etmeyip Horosan ilçesinden iki aileye Güllüdağ mahallesindeki 493 hektarlık yayla alanını kiraya vermektedir. Bu sahada 1876 küçükbaş hayvan beslenmektedir. Yaylaya geliş tarihleri 10 Mayıs-15 Ekim arasındadır. İlçede Alacayar köyüne ait Karşem yaylası, Yukarıyayla köyüne ait Sultan ve Çamlıyayla köyüne ait Dazlak yaylaları bulunmaktadır. Dazlak yaylası 1.7378 dekarlık alanıyla geniş çayırların olduğu bir sahadır. Narman ilçesinde en alt basamakta bulunan Yanıktaş yaylası $(2200 \mathrm{~m})$, en üst basamakta Güvenlik yaylası $(2565 \mathrm{~m})$ bulunurken yaylaların ortalama yükseltisi 2340 m'dir. Narman yaylaları daha çok Devre Dağı ve plato sahasında yer almaktadır. Narman Çayı ve kolları tarafından işlendiği için yaylacılık faaliyetlerine uygun koşullar taşımaktadır. Narman ilçesinde büyükbaş hayvancıllğa yönelik faaliyetler ön planda olup çayır ve mera alanlarında yürütülmektedir.

Tortum ilçesindeki yayla alanları Tunceli, Şanlıurfa ve Elazığ'dan gelen yaklaşık 70 aileye kiralanmaktadır. Kiralanan yayla alanı 3183 hektar olup bu yaylalara 10.685 küçükbaş hayvan çıkartılmaktadır. Hamidiye ve Aktaş köyleri yaylaları Mayıs-Eylül ayları arasında göçer gruplar tarafından kullanılmaktadır. Bu yaylalar dışındaki alanlarda sadece Taşoluk köyü mevcut küçükbaş hayvancılık faaliyetiyle (4103 baş) mera hayvancılığını yürütmektedir. Diğer yerleşmelerde sadece büyükbaş hayvanc1lık faaliyeti yürütülmektedir. İlçenin mevcut hayvan varlı̆g 26.700 büyükbaş ve 13.800 küçükbaştan oluşmaktadır. Tortum'da en az yükseltiye sahip yayla yerleşmesi $1185 \mathrm{~m}$ ile Cirdiniş, en fazla yükseltiye sahip yayla yerleşmesi 
ise $2675 \mathrm{~m}$ ile Ziyaretli yaylasıdır. Tortum Çayı tarafından işlenen alanda yayların ortalama yükseltisi 2310 m’ye karşıllk gelmektedir.

Oltu İlçesinde yer alan yayla yerleşmeleri Küçükkorucuk, Başaklı, Kaleboğazı, Sivri (Özdere) ve Damlıca (Ünlükaya) olup daha çok ismini dahil olduğu köy yerleşmelerinden almıştır. Başaklı (806 dekar) ve Damlıca (507 dekar) yaylaları çayır ve mera alanlarının en geniş olduğu yaylalara karşılık gelirken ilçeye bağlı yaylalar dışardan göçer gruplara kiralanmamaktadır. Oltu ilçesinde de sahaya dahil köylerde büyükbaş hayvancılık faaliyeti yürütülmektedir. İlçede en az yükseltiye sahip olan yayla Aşağıcivarı $(1283 \mathrm{~m}$ ) olup en fazla yükseltiye sahip yayla yerleşmesi ise Orucuk'tur (2484 m). Kargapazarı Dağlık kütlesinin kuzeydoğu ucuna karşılık gelen yaylaların ortalama yükseltileri 2100 m’dir.

Yakutiye ilçesinde bu sahada Karagöbek, Köşk, Şenyurt ve Söğ̈̈tyanı köyleri yaylacılık faaliyetlerinin yürütüldüğü alana karşılık gelmektedir. Kargapazarı dağlarının batı yamaçlarında yer alan bu sahalarda yükselti 2300-2400 m'ler arasındadır. Karasu Çayı tarafından drene edilen alan geniş doğal çayırlarının uzandığı bir sahadır. İlçede 374.285 dekarlık çayır ve mera alanı bulunurken, hayvan varlığı açısında 35.855 büyükbaş, 13.382 küçükbaş hayvan yer almaktadır. Bu sahadaki yaylalar Erzincan, Elâzığ, Tunceli ve Diyarbakır illerinden gelen 55 aileye kiralanmaktadır. Köşk ve Akdağ mahallerinin ihtiyaç fazlası yaylaları kiralanmakta olup, 6050 küçükbaş hayvanın beslendiği bir sahaya karşıllk gelmektedir. Köşk mahallesinde 17.500 dekar ve Akdağ mahallesinde de 3.000 dekarlık saha yaylacı gruplara her yıl kiralanmaktadır. Yaylacılık faaliyetleri mayıs ayının ikinci haftası ile ekim ayının ilk haftası arasında yapılmaktadır.

Yaylalar 2886 say1l ihale yasası ile kiraya verilmektedir. Belirlenen bir günde ihale yapılır ve en yüksek fiyatı veren kişiye kiralanmaktadır. Ancak yönetmeliğe göre ihale yasasında fiyat sabit görünürken her yıl fiyat artışı gözlemlenmesi yaylacılar tarafından hoş karşılanmamaktadır. İhaleyi alan kişiye resmiyette de yayla kiralanır bu durum güvenlik sorunları çıkmaması açısından oldukça önemlidir.

Kargapazarı yaylaları Erzurum dışından da gelen pek çok yaylacı gruba y1llardan beri ev sahipliği yapmaktadır. Gelen göçebe gruplar genellikle aynı yerleri sürekli kiralayarak yaylacılık faaliyetini sürdürmektedir. Özellikle aynı boy-soy gruplarına mensup akrabalık ilişkileri bulunan yaylacılar artık geleneksel anlamda da bu faaliyeti yürütmektedir. Gelen gruplar daha çok karın yerden kalkma süresinin erken olduğu, yükseltinin azaldığı ova, alçak plato sahaları ve havza tabanları gibi morfolojik ünitelerde kurulan ve hayvanc1lık faaliyetini yürüten yarı yerleşik göçebe toplumlardır. Elazığ ve Tunceli illerinde yarı yerleşik düzen oluşturan Şavaklılar geçmişten beri Kargapazarı yaylalarından yararlanmaktadırlar. Şavaklılar 4-12 kişilik gruplar halinde Büyükdere, Başören ve Köşk köylerine ait yaylalara çıkmaktadırlar. Bu yaylalar asıl Kargapazarı Dağlık kütlesi üzerinde yer alan plato sahalarına karşılık gelmektedir. Yaylacılık faaliyeti, dikey ritmik hareketlilik olarak adlandırılsa da bu faaliyet birdenbire yapılmamaktadır. Elazığ (Merkez) ve Tunceli'den (Pertek-Çemişgezek) çıkan göçebe gruplar aşama aşama yol kat ederek önce Bingöl ve Şerafettin Dağlık Ünitelerinde yaklaşık bir aylık süre geçirerek buradaki karın yerden kalkmasını beklemektedirler. $\mathrm{Bu}$ açıdan Bingöl ve Şerafettin Dağları ve yaylaları, geçiş alanları olarak kabul edilmektedir. Elazığ ve Tunceli'de hareketlilik Nisan ayının sonu ile Mayıs ayının başında başlamaktadır. Bu faaliyet göçebe grupların, Haziran ayının başında yaylalara ulaşmasıyla son bulur. $\mathrm{Bu}$ alanda altı aylık bir süreye denk gelen yaylacılık faaliyeti Kargapazarı yaylalarında 3 ay gibi bir süreye karşıllık gelir. Elazığ ve Tunceli'den yaklaşık 85 kişi ve 8100 hayvanla yaylacılık faaliyetine katılmaktadır.

Güneydoğu Anadolu Bölgesinde ise yaylacılık faaliyetine katılanlar Diyarbakır (Çermik, Ergani) ve Şanlıurfa (Siverek, Karacadağ) illerinde bulunan küçükbaş hayvancılıkla uğraşan gruplardır. Bölgede karın erken yerden kalkması otların erken sararması gibi iklimsel faktörler bu grupları Kargapazarı Bölgesine yöneltmiştir. Elazığ ve Tunceli'den burayı tercih eden gruplar değişmezken Diyarbakır ve Şanlıurfa illerinden gidenler sürekli değişmektedir. Bu illerden yaklaşık 65 kişi 5000 küçükbaş hayvanla yaylacılık faaliyetine katılmaktadır. Diyarbakır ve Şanlıurfa'dan gelen gruplar Bingöl-Şerafettin Dağları ve Muş Güneyi Dağlarındaki yaylaları da geçici olarak kullanmaktadırlar. $\mathrm{Bu}$ yaylalar da yakın dönemlere kadar yaşanan güvenlik problemlerinden dolayı Kargapazarı Dağları güvenli bölge olarak tercih edilmektedir.

Yaylacı gruplar 1-10 Haziran ve 1-20 Eylül tarihleri arasında yaklaşık 3 aylık bir dönemde buradaki yaylaları kiralayarak yaylacılık faaliyetlerini yürütmektedirler. En çok tercih edilen alanlar Büyükdere, Başören ve Köşk köylerine ait yaylalar olup, asıl Kargapazarı Dağları kütlesi üzerinde Tortum ve Büyükdere çaylarının bulunduğu sahalardır. Bu alanlar hidrografik açıdan oldukça yoğun parçalanmış yaklaşık 2500-2800 m'ler arasındaki yükselti kuşağına karşılık gelmektedir. Yaylaların da yoğun bulunduğu bu saha Türkiye yaylacılığının en üst zonlarından biridir. Şöyle ki bu saha Türkiye'de yıllık ortalama sıcaklıkların 
5-10 ${ }^{\circ} \mathrm{C}$ arasında olduğu şiddetli karasal iklim tipinin görüldüğü bir alandır. Hidrografik açıdan üç farklı havzanın kaynak noktasını oluşturur iken yaz yağışlarının ilkbahardan sonra \%24'lük oranla görüldüğü ve geniş çayır alanlarının olduğu önemli bir kuşaktır. Kar örtülü gün sayısı bu sahada 83-112 gün arasında değişmektedir. Dolayısıyla Yukarı Fırat Bölümü ve Güneydoğu Anadolu Bölgesi gibi Türkiye'de kar örtüsünün yerden erken kalktığı ve otların erken sarardığı bölgelerden bu alana doğru göçler Nisan ayından başlayıp aşamalı bir şekilde geçiş yaylaları aşıldıktan sonra yaylacılığın son evresini oluşturmaktadır. Güneydoğu Anadolu'da Nisan ayında kalkan kar örtüsü bu sahada Haziran ayının ortasına kadar devam etmektedir. Dolayısıyla bu sahanın hem hidrografik hem de bitki örtüsü açısından önemli bir kaynak alanı olarak ortaya çıkmasına neden olmuştur (Foto 2).

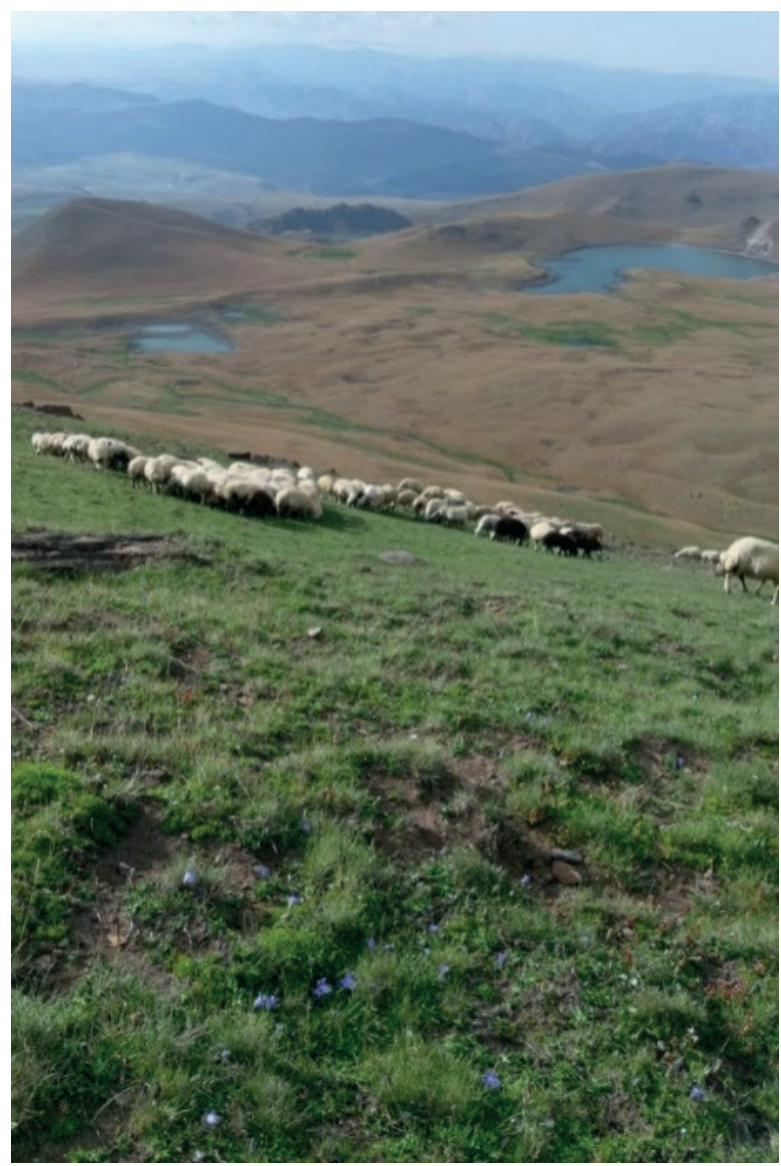

Foto 2: Kargapazarı Dağlık Kütlesi üzerinde yer alan göller ve mera alanından görüntü.

Photo 2: A view from the lakes and pasture areas on the Kargapazarı Mountainous Mass.

Araştırma sahasında yaylacılı̆̆ın önemli bir tercih alanı olmasında özellikle Tunceli yaylalarında yaşanan güvenlik probleminin rolü oldukça büyüktür. Şavak yöresi olarak bilinen (Pertek-Çemişgezek) bu alanlarda Kargapazarı Dağlarına ilgi çok fazladır. Bingöl-Şerafettin ve Muş Güneyi yaylalarında da benzer sorunların yaşanması göçebe grupları bu sahaya yöneltmiştir. Güvenlik problemlerinin yanı sıra ulaşım açısından da oldukça elverişli şartlar sunması tercih edilmesinde önemli bir kıstastır.

Yaylaya ulaşım 1990 yıllarından önce genellikle binek-yük hayvanları ile yapılırken bu tarihten sonra ulaşım araçlarının gelişmesine bağlı olarak 3 katlı kamyon "canlı hayvan taşıma araçları" kullanılmaya başlanmıştır. Yaylalarda hayvanlar için kalınacak barınaklar bulunmadığı ve araçlarla yaylalara çıkartıldığı için iklimsel farklılıklardan dolayı birçok hayvan hastalanarak telef olmaktadır. Bu duruma önlem alabilmek içinde genellikle hayvanlara aşı yapılmaktadır. Çünkü yaylacılık faaliyetine katılmadan önce gelinen yerler ile yayla alanlarının iklimi arasında bariz farklar bulunmaktadır. Hayvanlar araçlarla taşındığı için adaptasyon sorunu yaşanmaktadır. Yaylalara ulaşımda karayolu tercih edildiği için sadece kontrol amaçlı belirlenen alanlarda hayvanlara bakılmaktadır. Örneğin Elazığ'dan çıkan bir grup Çevre yolu, Koçkale, BingölKervansaray-Soğuk Çeşme ve Erzurum-Çat gibi yerlerde kontrolü yapılmaktadır.

Hayvanlar taşınırken yaylaya direkt olarak çıkartılır. Yayla dönüşlerinden yürünerek belli bir yere kadar gelinir daha sonra araçlara yükleme yapılır. Örneğin Elazığ'a gelecek olan bir sürünün yol güzergâhı şöyle olmaktadır. Yayladan dönüş esnasında Köşk köyünün doğusuna gelinir, Erzurum sınırından Güzelova-Kösemehmet Köyü'nden geçilerek Erzurum'un doğusundaki Nenehatun'a ulaşılır. Nenehatun yolundan Toparlak Köyü ve Palandöken'e geçilerek Kırmızı mezar, Ali Şeref yaylalarına ulaşı1ır. Bu yaylalar Erzurum'un güneydoğusunda Palandökene bağlı Tekman yolu üzerinde yer almaktadırlar. Sonraki aşamada ise Erzurum-Bingöl yolu üzerinden Bakımevine geçilir sırasıyla Adaklı, Sancak, Karakoçan, Kovancılar üzerinden Gülüşkür Köprüsüne ulaşılır. Bu köprüden geçmenin yasak olması ve devletin Koçkale taraflarını ormanlaştırması, buradaki köylülerin zorluk çıkartmasına sebep olmaktadır. Örneğin Diyarbakır'a giden bir grubun dönüş yolu güzergâhı Kovancılar'a kadar aynı olup Palu ve Maden ilçelerinden geçerek Ergani üzerinden kışlak alanlarına (Diyarbakır havzası ve Karacadağ platosu) ulaşılır. Tunceli'ye giden bir grubun yol güzergâhı hemen hemen aynı olup Kovancılar üzerinden Mazgirt'e oradan da Pertek'e geçilir. Köye ulaşmak için de hayvanlar tekrar araçlara bindirilir.

Göçebelerin yılın belli bir süresi içinde, çoğunlukla kış aylarında, sabit konutlarda oturmaya ve tarımla uğraşmaya 
başlamaları, yılın geri kalan kısmını ise göçlerle yaylalarda geçirmeleri ve buralarda da çadırda yaşamaları bir tür göçebeliktir. Ancak, göçebelerin hayatında tarımın yer alması ve giderek yerleşik hayata geçiş, göçebelikten çok bir ara tip ya da geçiş biçimi olan yarı göçebelik kavramı ile açıklanmaktadır. Göçebelik ile yerleşiklik arasında bir hayat tarzı olan yarı göçebelik, göçebelikten yerleşik düzene geçişin bir evresi olarak kabul edilebileceği gibi, başlı başına bir ekonomik sistemde olabilmektedir (Kutlu, 1987, 22). Kargapazarı dağlık ünitesinde göçer gruplar genellikle obalar halinde mesken tipi olarak çadırlarda yaşarlar. Kıl çadırın yerini günümüzde daha modern (fabrikasyon) çadırlar almıştır (Foto 3).
Yaylalarda kullanılan çadırlar genellikle geniş bölmeleri olup tıpkı kalıcı konutlar gibi çeşitli fonksiyonları da barındırmıştır (Foto 4). Hijyen sağlamak amacıyla yerel yönetimler tarafından yaylalarda banyo, tuvalet gibi eklentiler yapılarak daha kullanılır hale getirilmektedir. Yine ürünün tazeliğini korumaya yönelik çeşitli depolarla birlikte yayla da kullanılan eklenti sayısı artmaktadır.

Yaylacı gruplarla yapılan mülakatlar sonucunda karşılaşılan sorunlar belirlenmiştir. Bu sorunlar genel olarak yayladan inişte karşılaşılan sorunlar, sürü sahiplerinden kaynaklı sorunlar ve planlamadan kaynaklı sorunlar olarak 3 ana başlık altında toplanmıştır.

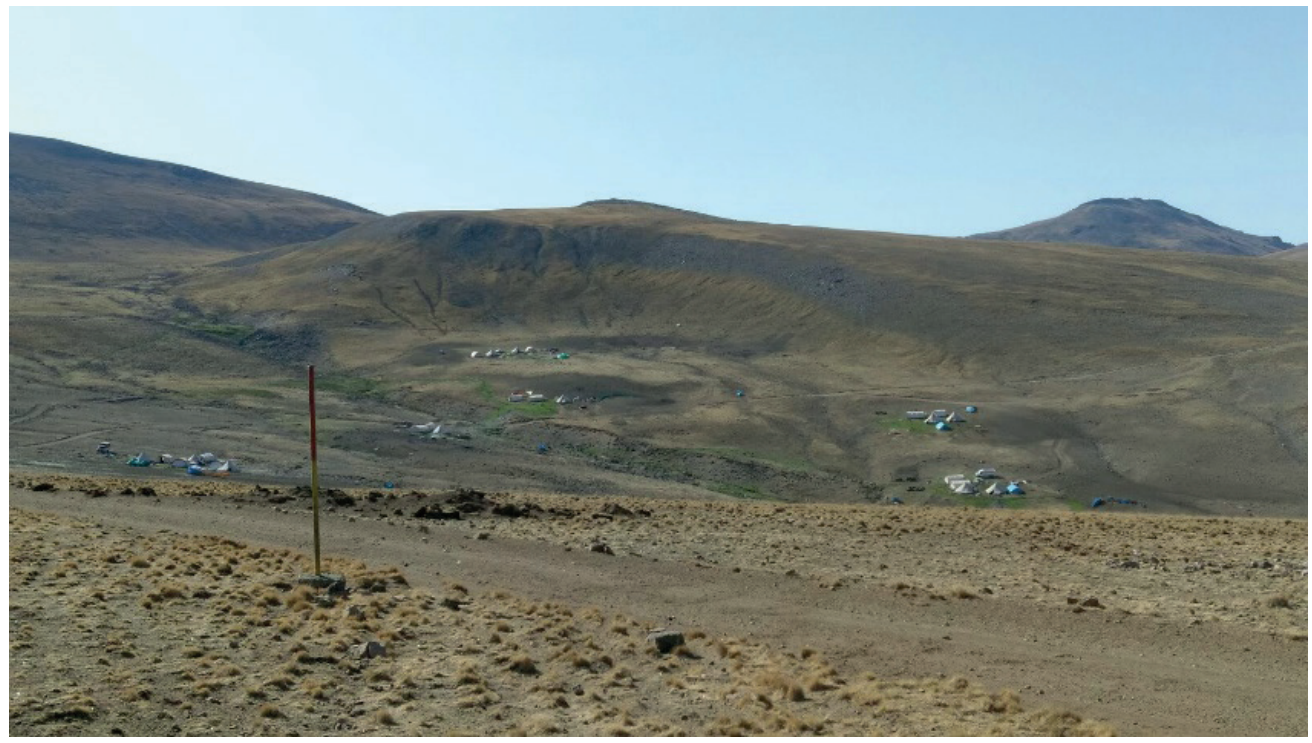

Foto 3: Kargapazarı Yaylalarında obalar halinde kurulan çadır meskenler.

Photo 3: Tent wellings set up in the Kargapazarı Highlands in the nomadic camping sites.

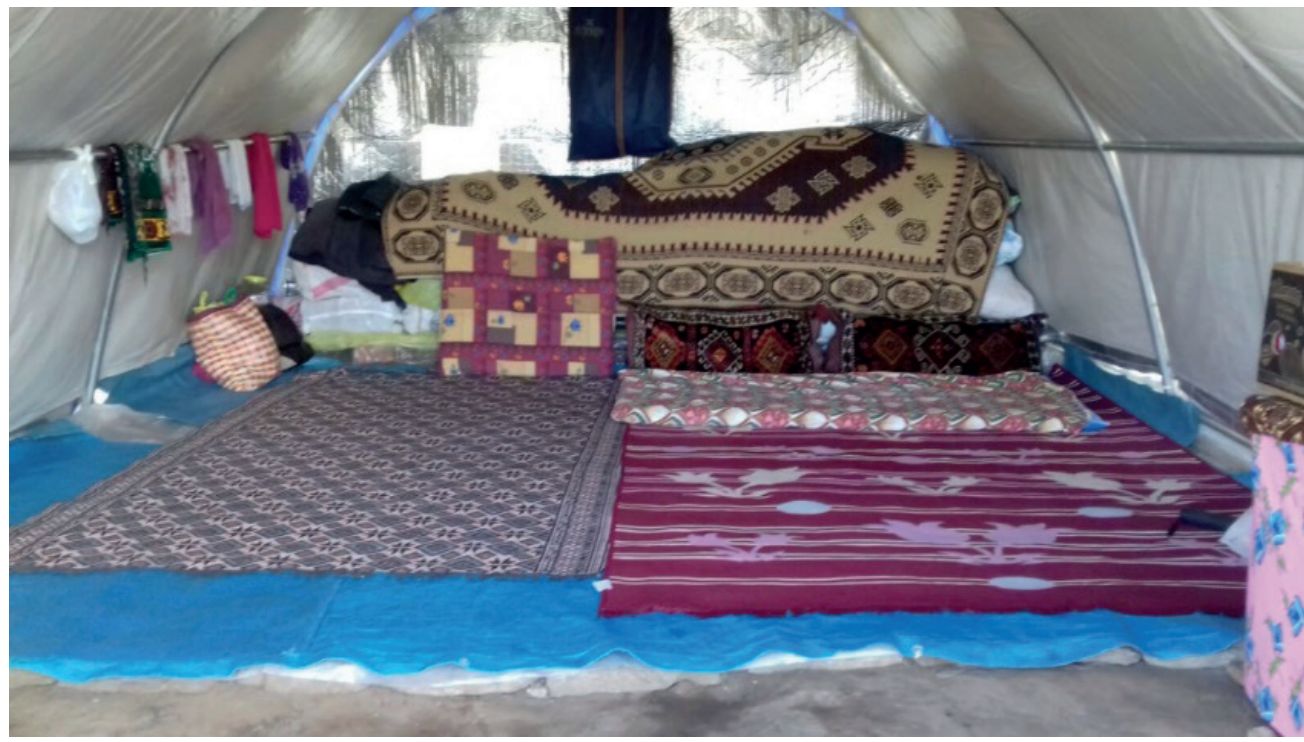

Foto 4: Kargapazarı dağlık ünitesinde kurulan çadırların iç bölmesinden görüntü. Photo 4: A view from the inner part of the tents set up in Kargapazarı mountainou sunit. 
İnerken karşılaşılan sorunlar; köylerin kendilerine aitmera alanlarından hayvan sürülerinin geçmelerine izin vermemesi ve bunu da firsat bilerek sürü sahiplerinden koyun ya da belli bir miktarda para alması, sürülerin her yıl geçtikleri yerlerin belli olması ve bunu bilerek hayvanların su içeceği yerlerdeki suların kirletilmesi, Mera Yönetmeliğinde yer almasına rağmen bazı tarım il müdürlüklerinin yaya yolu raporu vermemesi, Çeşitli hayvan hastalıklarının olması. Bazı köylerin de hayvanları hasta olmasına rağmen bu durum ifade edilmeyip dönüş yolundaki diğer hayvanlara hastalığın bulaştırılması, hayvanların geçeceği yolların yasaklanması sonucunda alternatif yol güzergâhında yaşanan problemler sonucunda da birçok kaza meydana gelmekte ve sürü sahiplerinin zor durumda kalması ve sürülerin geçtikleri yerlere bilgilendirici tabelalar koyulmaması gibi sorunlar yaşanmaktadır.

Sürü sahiplerinin çıkardığ1 sorunlar; köylülerin kendi hayvanları için ayırmış oldukları mera alanlarının sürü sahipleri tarafindan otlatılması ve köylere ait tarlalara hayvanlar tarafindan zarar verilmesi, köylerin bulunduğu alanlarda hayvanların yerleşim birimlerinden geçirilmesi ve konutlara zarar verilmesi ve köylerin kirletilmesi gibi sorunlar yaşanmaktadır.

Planlamada karşılaşılan sorunlar; Pazarlamada değişken maliyetin olması, tulum peyniri satıcısı olmayan firmaların tulum peynirini ucuza pazara sürmesi sonucu diğer üreticilerin yani gerçek tulum peyniri üreticilerin bundan büyük oranda zarar görmesi,peynirin KDV'sinin yüksek olması, fiyatlarda standardın korunmaması ve kaliteli peynirin pazarlama konusunda eksikliklerinin olması sonucunda hak ettiği değeri görmemesi, doğal tulum peyniri yapım aşamalarının kontrol edilememesi peynirin kalitesinin korunmasına yönelik tedbirlerin alınmıyor olması ve firma sayılarının artması sonucunda hijyen denetiminin yeterli ölçüde yapılmaması.

\section{SONUC VE ÖNERILLER}

Erzurum ili Türkiye'de hayvancılık amaçlı yaylacılığın en önemli noktalarından biridir. İldeki yaylalar kuzeyde ÇoruhKelkit ve güneyde Karasu Aras sıradağları üzerinde yer alan geniş platolarda kurulmaktadır. Türkiye'nin adeta çatısı konumundaki bölge sahip olduğu hidrografya ve bitki örtüsü çeşitliliği sayesinde önemli yaylacılık sahası durumundadır. Bu alanda sadece yayla yerleşmeleri değil yükseltinin fazla olmasından dolayı kom ve mezra yerleşmeleri de yaylacılık faaliyeti için kullanılmaktadır. Sahada genellikle geniş çayırların varlığına bağlı olarak büyükbaş hayvancılık faaliyeti yürütülmektedir. Kargapazarı Dağlık Ünitesinin \%51'inin çayır ve meralardan oluşması yaylacılar için tercih nedenlerinden biridir. Küçükbaş hayvancılık faaliyeti yöre halkından ziyade dışarıdan gelen göçebe gruplar tarafından yürütülmektedir.

Özellikle Elâzığ, Tunceli, Diyarbakır ve Şanlıurfa illerinden Kargapazarı yaylalarına gelen göçer gruplar Doğu Anadolu Bölgesi'nin diğer alanlarında yaşanan güvenlik kaygısını ön planda tutmuştur. Nispeten diğer alanlara göre (BingölŞerafettin-Muş Güneyi-Munzur-Mercan Kütleleri) terör faaliyetlerinin görülmediği güvenli bir bölgedir.

Sahadaki yaylalar genellikle yükseltinin fazla olmasından dolayı kar erimelerinin geç olduğu ve iklimsel faktörler nedeniyle yaz yağışlarının İlkbahardan sonra ikinci sırada yer alması geniş çayır ve mera alanlarının varlığını sağlamıştır. Bundan dolayı da hem sahada yürütülen hem de dışarıdan gelen hayvancı gruplar için önemli bir avantaj oluşturmuştur. Şöyle ki günümüz hayvancılığının en önemli sorunlarından biri artan yem bitkisi fiyatlarıdır.

Kargapazarı Dağlık Ünitesinin dahil olduğu Otu, Narman, Pasinler, Tortum ve Yakutiye ilçelerinde toplam 96 yayla yerleşmesi yer alırken araştırma sahasında 30 adet yayla yer almaktadır. Yükseltileri değişmekle beraber kuzeydoğuya doğru gidildikçe yükselti azalmaktadır. Dağlık ünite üzerinde yaylaların kümelendiği alanlar asıl Kargapazarı Dağlık Kütlesi, Devre Dağ1 ve Çatal Dağı'dır. Yakutiye ve Pasinler yaylaları asıl dağlık kütle üzerinde yer alırken Tortum ve Narman yaylaları ağırlıklı olarak Devre Dă̆ı, Oltu yaylaları da Çatal Dağı üzerindeki plato sahalarında kurulmuştur.

Dağlık kütle üzerinde en az yükseltiye sahip yerleşmeler köy ve mezralardan oluşurken en fazla yükseltiye sahip yerleşmeler yaylalara karşılık gelmektedir. Yükseltiler açısından değerlendirildiğinde ortalama yükseltinin en fazla olduğu yaylalar Pasinler'e $(2360 \mathrm{~m})$ ait olup ilçeyi sırasıyla Narman (2340 m), Tortum (2310 m), Yakutiye (2290 m) ve Oltu (2100 m) yaylaları takip etmektedir. Dağlık kütle üzerindeki en fazla yükselti Güzel (2773 m-Yakutiye) yaylası iken en az yükseltiye sahip Güzelova (1948 m-Yakutiye) yaylasıdır.

Yukarı Firat Bölümü ve Güneydoğu Anadolu Bölgesi gibi nispeten yükseltinin daha az olduğu alanlarda Nisan ayı gibi karın yerden kalkması bu alandaki yaylacı grupların yılın altı ayını sürekli hareket halinde geçirmesine neden olurken bu harekette üç farklı nokta göze çarpmaktadır: Nisan ayında çıkan gruplar önce daha alt zondaki yaylalar olan Bingöl-Şerafettin, Sancak yaylalarında 20 gün ile 1 ay bekleyip üst zondaki karların erimesine bağlı olarak harekete devam edilmektedir. Bu dağlık 
kütle üzerinde yaylacılık süresi 3-3,5 ay gibi bir zaman dilimini kapsamaktadır.

Yaylada üretilen ürünler tüccarlar aracıllğıyla pazarlanır. Tüccar, yaylaya gelen kişilerden peyniri taze alarak ona uygun soğutucu araçlara yükleyip başta Elâzığ olmak üzere üretimin yapılacağı fabrikalara gönderilir ve üretimi yapılmaktadır. Üretilen peynirler başta İstanbul olmak üzere büyük şehirlere pazarlanmaktadir.

Pazarlamada karşılaşılan sorunlara yönelik yapılan mülakatlarda şu çözüm önerileri getirilmiştir; Pazarlama konusunda uzmanlaşmış kişilerden yardım alınmalı, bu alanda çeşitli kurslar açılarak pazarlama işiyle uğraşanlara gerekli eğitimlerin verilmesi sonucunda başarılı olanlara da uzmanlık belgesi verilmelidir. Pazarlamacıların pazarlama potansiyeli belirlenmeli, geçmiş dönemlerdeki yapılan çalışmalar incelenip, gelecek için uygun planlamalar yapılarak geçmişte yapılan hatalar tekrar edilmemelidir. Sahte üreticilere karşı yasalar caydırıcı olmalıdır.

Hakem Değerlendirmesi: Dış bağımsız.

Çıkar Çatışması: Yazar çıkar çatışması bildirmemiştir.

Finansal Destek: Yazar bu çalışma için finansal destek almadığını beyan etmiştir.

Peer-review: Externally peer-reviewed.

Conflict of Interest: The author has no conflict of interest to declare.

Grant Support: The author declared that this study has received no financial support

\section{KAYNAKÇA/REFERENCE}

Alagöz, C. A. (1941, Haziran). Yayla tabiri hakkında rapor. Birinci coğrafya kongresi: raporlar, müzakereler, kararlar içinde (s.150157). Ankara.

Alagöz, C. A. (1993). Türkiye'de yaylacılık araştırmaları. Ankara Üniversitesi Türkiye Coğrafyası Araştırma ve Uygulama Merkezi Türkiye Coğrafyası Dergisi, 2, 1-51.

Anonim, (1980). Toprak kaynaklarl il envanter raporlarl Erzurum. Ankara: Topraksu Genel Müdürlüğü Yayınları.

Arınç, K. (2011). Türkiye'nin iç bölgeleri. Erzurum: Eser Ofset Matbaacilik.

Corine (2012). Arazi kullanım verileri. Erişim adresi: http://www. corine.itu.edu.tr/

Darkot, B. (1975). Türkiye iktisadî coğrafyası. İstanbul Üniversitesi Coğrafya Enstitüsü Yayınları.

Denker, B. (1968). Güney doğu toroslarda göçebelik. Türk Coğrafya Dergisi, 20, 136-142.

Doğanay, H. ve Coşkun, O. (2013). Türkiye yaylacıllğındaki değişme eğilimleri ve başlıca sonuçları. Doğu Coğrafya Dergisi, 18(30), 1-28.
Doğanay, H. ve Orhan, F. (2016). Türkiye beşeri coğrafyası,Ankara: Pegem Akademi.

Doğanay, H. ve Zaman, S. (2004). Oba-yayla yerleşmelerine tipik iki örnek: Çambaşı ve Turnalık obaları (Ordu İli). Türk Coğrafya Dergisi, 43, 1-29.

Durmuş, E. ve Çağlıyan, A. (2010). Tunceli ilinde yaylacılık. Fırat Üniversitesi Doğu Anadolu Bölgesi Araştırmaları Dergisi, 8(1), 84102.

Emiroğlu, M. (1974). Erzurum Kır Yerleşmelerinin Ortalama Yüzölçümleri, Parsel Sayıları ve Büyüklükleri İle İlgili Bir Araştırma. Ankara Üniversitesi Dil ve Tarih-Coğrafya Fakültesi Dergisi, 28(1-2), 156-195.

Emiroğlu, M. (1977). Bolu'da yaylalar ve yaylacılık (No: 272). Ankara Üniversitesi Dil ve Tarih-Coğrafya Fakültesi Yayınları.

Erinç, S. (1953). Doğu Anadolu coğrafyası (No: 15). İstanbul Üniversitesi Coğrafya Enstitüsü Yayınları.

Erinç, S. (1972). Türkiye: insan ve ortam. Güneydoğu Avrupa Araştırmaları Dergisi, 1, 165-194.

Harita Genel Müdürlüğü, 1/100.000 Ölçekli G 45-49, H 44-49, İ 44-49, J 45-48 Erzurum Paftaları.

Hütteroth, W. D. (1959). Bergno maden und Yayla bauern im mittleren kurdischen Taurus. Marburger Geographische Schriften 11. Marburg: Selbstverlagdes Geographischen Instituts der Universität Marburg.

Koday, S. (1999). Hınıs İlçesi’nde kom yerleşmeleri üzerine bir araştırma. Türk Coğrafya Dergisi, 34, 357-382.

Koday, S. (2005). Doğu Anadolu bölgesinde hayvancılık (No:949). Erzurum: Atatürk Üniversitesi Yayınları.

Kutlu, M. (1987). Şavaklı Türkmenlerde göçer hayvancılık (No:84). Ankara: Kültür ve Turizm Bakanlığı Milli Folklor Araştırma Dairesi Yayınları.

Maden Tetkik ve Arama Genel Müdürlüğü (2002). 1/500.000 Ölçekli Türkiye Jeoloji Haritası, Trabzon Paftası.

Merriam, G. P. (1926). Theregional geography of Anatolia. Economic Geography, 2(1), 86-107.

Meteoroloji Genel Müdürlüğü 1995-2018 İklim verileri. Erişim adresi: https:/www.mgm.gov.tr/iklim/yayinlar.aspx

Özav, L. (1991). Narman'da mesken tipleri. Atatürk Üniversitesi FenEdebiyat Fakültesi Edebiyat Bilimleri Araştırma Dergisi, 19, 153172.

Özav, L. (1994a). Gediz-Ilıca termal turizm merkezi. Türkiye Kalkınma Bankası Turizm Yıllı̆̆g, 230-246.

Özav, L. (1994b). Oltu bölgesinde köy yerleşme şekilleri. Türk Dünyası Araştırmaları, 92, 168-186.

Özav, L. (1995). Narman'da nüfus hareketleri. Atatürk Üniversitesi Fen-Edebiyat Fakültesi Edebiyat Bilimleri Araştırma Dergisi, 21, 79-102.

Özav, L. (1995). Oltu (Erzurum) ilçesindeki köy yerleşmelerinin coğrafi özellikleri ile ilgili bir inceleme. Atatürk Üniversitesi Doğu Coğrafya Dergisi, 1, 336-361.

Özey, R. (1985). “Güzelyayla köyü yaylası”, Türk Dünyası Araştırmaları Dergisi, 34, 204-215. 
Özey, R. (1987). Dumlu ve çevresinde kom yerleşmeleri, Türk Dünyası Araştırmaları Dergisi, 49, 119-126.

Özey, R. (1990). Fırat-Karasu kaynakları çevresinde köy yerleşmeleri: Dumlu ve çevresi, Fırat Havzası. (14-15 Nisan 1986) Coğrafya Sempozyumu Bildiriler Kitabı içinde (s. 213-234). Elazı̆̆.

Saraçoğlu, H. (1989). Doğu Anadolu bölgesi. İstanbul: Milli Eğitim Basımevi.

Sözer A.N. (1972). Kuzeydoğu Anadolu'da yaylacılık. Ankara: İş Matbaac1lik ve Ticaret.

Topraksu (1980). Erzurum ili arazi varlığı. Ankara: T.C. Sanayi ve Ticaret Bakanlığı.

Tunçdilek, N. (1967). Türkiye iskân coğrafyası, kır iskânı: köy-altı iskân şekilleri (No:49). İstanbul Üniversitesi Coğrafya Enstitüsü.

Tunçel, H. (2015). Coğrafyanın yaylacılık literatürü üzerine bir değerlendirme. H. Tunçel (Ed.), Yayla Kültürü ve Yaylacılık Sempozyumu içinde (s.5-26), Bilecik.

Türkiye İstatistik Kurumu 1980-2018 Nüfus istatistikleri. Erişim adresi: https://biruni.tuik.gov.tr/medas/?kn=95\&locale $=$ tr

Türkiye İstatistik Kurumu 1995-2018 Hayvancıllk istatistikleri. Erişim adresi: https://biruni.tuik.gov.tr/medas/?kn=101\&locale=tr
Yılmaz, O. (1991). Tortum gölü çevresinde mezra yerleşmeleri. (20-24 Kasım 1991) Atatürk Kültür Dil ve Tarih Yüksek Kurumu ve Ege Üniversitesi Edebiyat Fakültesi Coğrafya Meslek Haftası Bildiri Özetleri içinde (s. 61-62), Ankara.

Y1lmaz, O. (1991). Tortum'da nüfus hareketleri. Atatürk Üniversitesi Fen-Edebiyat Fakültesi Edebiyat Bilimleri Araştırma Dergisi, 19, 115-134.

Y1lmaz, O. (1995). Tortum gölü (Erzurum) çevresinde mezra yerleşmeleri. Süleyman Demirel Üniversitesi Fen-Edebiyat Fakültesi Sosyal Bilimler Dergisi, 1, 336-343.

Yiğit, A. (2015). Türkiye'de yaylacılık faaliyetlerinin gerilemesi ile karın yerde kalma süresi arasındaki ilişkiler. H. Tunçel (Ed.), Yayla Kültürü ve Yaylacılık Sempozyumu içinde (s.133-148), Bilecik.

Yüksek, T. (2002). Çoruh havzasında yaylacılık faaliyetleri ve karşılaşılan sorunlar. (25-27 Haziran 2002) Türkiye Dağları 1. Ulusal Sempozyumu Bildiriler Kitabı içinde (s. 285-288), Kastamonu.

Zaman, S. (2007). Fonksiyonel değişim sürecinde Antalya Beydağları yaylaları. Erzurum: Atatürk Üniversitesi Yayınları No: 967, Kâzım Karabekir Eğitim Fakültesi Yayınları No: 125. 